\title{
Antarctic phytoplankton community composition and size structure: importance of ice type and temperature as regulatory factors
}

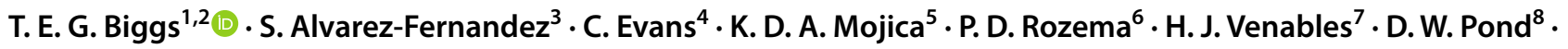 \\ C. P. D. Brussaard ${ }^{1}$
}

Received: 6 December 2018 / Revised: 4 July 2019 / Accepted: 28 August 2019 / Published online: 6 September 2019

(c) The Author(s) 2019

\begin{abstract}
Climate change at the Western Antarctic Peninsula (WAP) is predicted to cause major changes in phytoplankton community composition, however, detailed seasonal field data remain limited and it is largely unknown how (changes in) environmental factors influence cell size and ecosystem function. Physicochemical drivers of phytoplankton community abundance, taxonomic composition and size class were studied over two productive austral seasons in the coastal waters of the climatically sensitive WAP. Ice type (fast, grease, pack or brash ice) was important in structuring the pre-bloom phytoplankton community as well as cell size of the summer phytoplankton bloom. Maximum biomass accumulation was regulated by light and nutrient availability, which in turn were regulated by wind-driven mixing events. The proportion of larger-sized ( $>20 \mu \mathrm{m})$ diatoms increased under prolonged summer stratification in combination with frequent and moderate-strength wind-induced mixing. Canonical correspondence analysis showed that relatively high temperature was correlated with nano-sized cryptophytes, whereas prymnesiophytes (Phaeocystis antarctica) increased in association with high irradiance and low salinities. During autumn of Season 1, a large bloom of 4.5- $\mu \mathrm{m}$-sized diatoms occurred under conditions of seawater temperature $>0{ }^{\circ} \mathrm{C}$ and relatively high light and phosphate concentrations. This bloom was followed by a succession of larger nano-sized diatoms $(11.4 \mu \mathrm{m})$ related to reductions in phosphate and light availability. Our results demonstrate that flow cytometry in combination with chemotaxonomy and size fractionation provides a powerful approach to monitor phytoplankton community dynamics in the rapidly warming Antarctic coastal waters.
\end{abstract}

Keywords Cellular carbon $\cdot$ Flow cytometry $\cdot$ Ice type $\cdot$ Pigments $\cdot$ Size fractionation $\cdot$ Temperature

Electronic supplementary material The online version of this article (https://doi.org/10.1007/s00300-019-02576-3) contains supplementary material, which is available to authorized users.

T. E. G. Biggs

tristan.biggs@nioz.nl

C.P. D. Brussaard

corina.brussaard@nioz.nl

1 Department of Marine Microbiology and Biogeochemistry, NIOZ Royal Netherlands Institute for Sea Research, and University of Utrecht, Texel, The Netherlands

2 Department of Freshwater and Marine Ecology, Institute for Biodiversity and Ecosystem Dynamics (IBED), University of Amsterdam, Amsterdam, The Netherlands

3 Alfred Wegener Institut Helmholtz Zentrum für Polar und Meeresforschung, Biologische Anstalt Helgoland, Helgoland, Germany
4 Ocean Biogeochemistry \& Ecosystems Research Group, National Oceanography Centre, Southampton, UK

5 Department of Botany and Plant Pathology, Oregon State University, Cordley Hall, Corvallis, OR 2082, USA

6 Department of Ocean Ecosystems, Energy and Sustainability Research Institute Groningen, University of Groningen, Groningen, The Netherlands

7 British Antarctic Survey, Natural Environmental Research Council, Cambridge, UK

8 Institute of Aquaculture, University of Stirling, Stirling, Scotland, UK 


\section{Introduction}

Global climate change will have consequences for marine ecosystems throughout the world's oceans (Boyce et al. 2010; Hallegraeff 2010). In polar marine ecosystems, the impact of a warming climate is magnified because a relatively small change in temperature can have a large impact on sea ice melt and ice cover (Smetacek and Nicol 2005; Schofield et al. 2010). In the Antarctic, declines in sea ice have been associated with a longer growing season and consequently, higher annual net production (Moreau et al. 2015). However, the influence of sea ice is complicated by variability in relation to the extent as well as the timing of advance and retreat which may be largely influenced by local-scale, rather than large-scale, forcing (Kim et al. 2018). Decreased ice cover has been associated with a reduction in photosynthetic efficiency (Schofield et al. 2018) and several studies have described a reduction in overall phytoplankton biomass and a shift from large phytoplankton (diatoms) to smaller flagellated species. These shifts have been associated with reduced salinities, higher temperatures and stronger vertical stratification (Moline and Prezelin 1996; Moline et al. 2004; MontesHugo et al. 2009; Venables et al. 2013; Mendes et al. 2017; Rozema et al. 2017c). However, the physicochemical drivers behind community shifts towards flagellated phytoplankton remain unclear, likely due to the diversity among flagellated phytoplankton spanning different taxonomic groups and cell sizes, and each may interact differently with the physicochemical environment. Our current understanding of the drivers associated with the seasonal progression within the phytoplankton community (Henley et al. 2019), particularly the pico- $(\leq 3 \mu \mathrm{m})$ and nano-sized (>3-20 $\mu \mathrm{m}$ ) phytoplankton, limits our ability to accurately predict how polar marine systems will respond to future climate change with implications for food-web dynamics and the marine carbon cycle (e.g. Pinhassi et al. 2004; Conan et al. 2007; Christaki et al. 2008; Obernosterer et al. 2008; Agustí and Duarte 2013; Evans et al. 2017).

Cell size is an important functional trait that influences almost every aspect of phytoplankton biology (Marañón 2015). Phytoplankton community size structure is therefore a key factor regulating food-web dynamics, biogeochemical cycling and trophic carbon transfer in the marine environment (Finkel et al. 2010; Marañón 2015). Shifts in the size class of primary producers in productive regions may also affect ocean carbon sequestration (the biological pump) as the larger phytoplankton (e.g. diatoms) are typically grazed by large copepods and krill (Quetin and Ross 1985; Jacques and Panouse 1991; Kopczynska 1992; Granli et al. 1993), whereas the smaller-sized cells (flagellates) are grazed by salps, small copepods and protozoans
(Harbison et al. 1986; Riegman et al. 1993; Froneman and Perissinotto 1996; Perissinotto and Pakhomov 1998). As a result, obtaining a mechanistic understanding of the factors that control the variability of phytoplankton community size structure remains a central goal in biological oceanography (Marañón 2015).

The Western Antarctic Peninsula (WAP) has experienced rapid climate change (Saba et al. 2014) resulting in alterations in phytoplankton community structure (Beardall and Stojkovic 2006; Deppeler and Davidson 2017; Rozema et al. 2017c), which are evident at higher trophic levels, with shifts in the grazer community from krill to the nutritionally poorer salps (Loeb et al. 1997; Atkinson et al. 2004; Saba et al. 2014; Steinberg et al. 2015). Moreover, reduced viral activity predicted due to changes in host population dynamics (Evans et al. 2017), may exacerbate impacts on community structure due to reduced substrate availability for microbial loop processes. Although the WAP area has been studied in quite some detail over the last 20 years, to our knowledge, no studies have simultaneously investigated the size class distribution of Antarctic phytoplankton abundances using flow cytometry (FCM) and chemotaxonomy (CHEMTAX). Thus far, WAP phytoplankton communities have been examined using mostly light microscopy and/or pigment-based taxonomic analysis (Garibotti et al. 2003, 2005; Rozema et al. 2017c). Studies using flow cytometry (FCM) to investigate phytoplankton community composition and examine environmental drivers are still lacking. Furthermore, fractionated Chlorophyll-a (Chl-a) studies did not include taxonomic distinction of the different size classes and investigated long-term trends and inter-seasonal differences rather than intra-seasonal variation (Clarke et al. 2008; Rozema et al. 2017c). Here we describe phytoplankton community dynamics (abundances, taxonomic composition and size of single cells) over two consecutive productive seasons. The combination of FCM and CHEMTAX, with size fractionation, potentially represents a powerful approach to uncover physicochemical factors structuring phytoplankton community size structure, particularly the pico- and nanosized classes.

\section{Methods}

\section{Study area and sampling}

Data for this study were obtained at the Rothera time series site (RaTS, latitude $67.572^{\circ} \mathrm{S}$; longitude $68.231^{\circ} \mathrm{W}$; Clarke et al. 2008) located in Ryder Bay on the WAP (Fig. 1). Samples were taken over two consecutive austral productive seasons designated S1 (November 2012 to April 2013) and S2 (November 2013 to April 2014). Discrete seawater samples were collected from $15 \mathrm{~m}$ depth by a 12-L Niskin bottle 


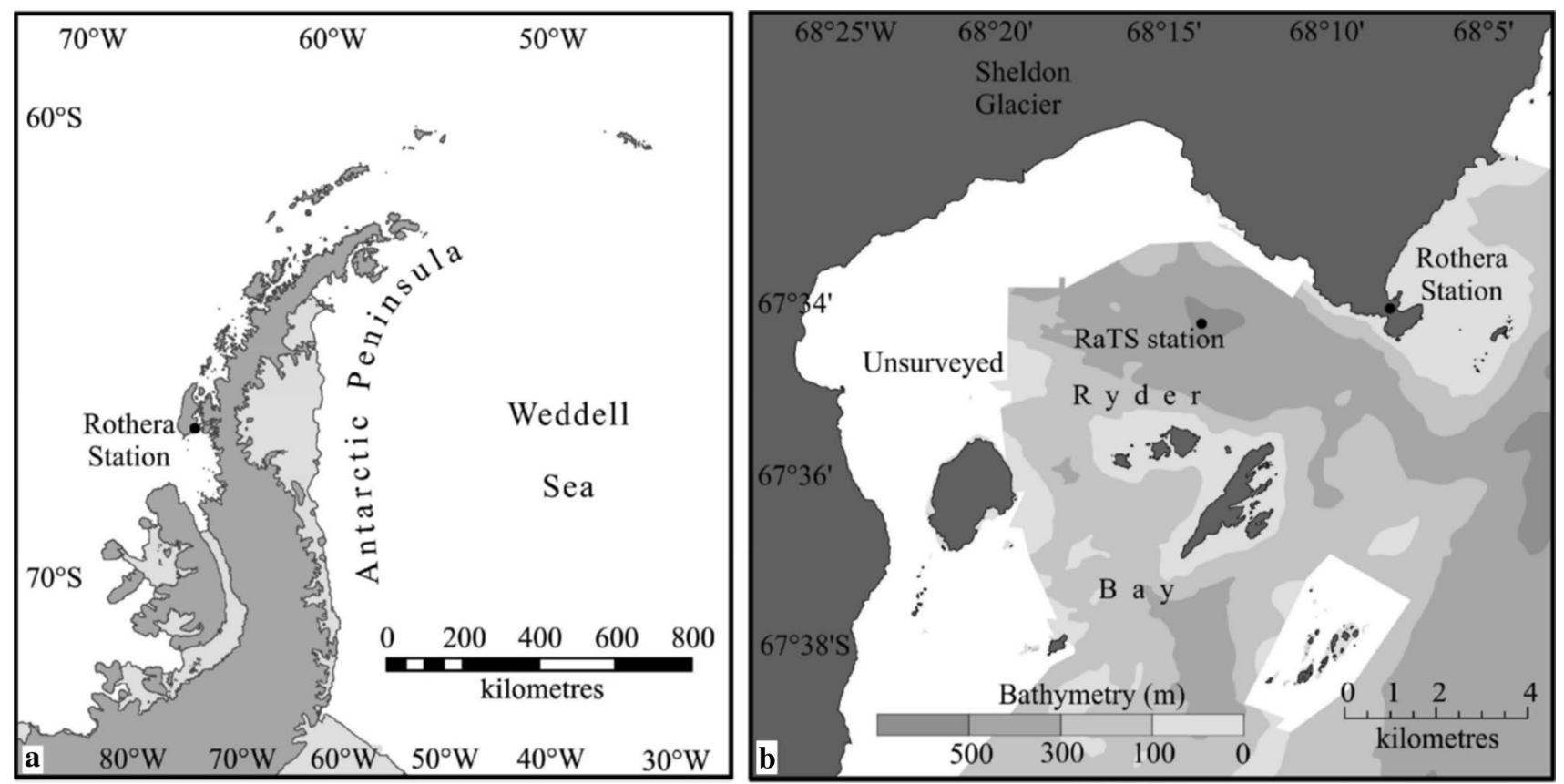

Fig. 1 Map of the sampling area: a location of Rothera station on the northern tip of Marguerite Bay along the Western Antarctic Peninsula, b large-scale map of the sampling site within Ryder Bay and close to Rothera station

deployed from a small boat. Full water column profiles were obtained using a SeaBird 19+ conductivity temperature depth instrument (CTD) supplemented with a flat LiCor sensor to measure photosynthetically available radiation (PAR) and an in-line fluorescence sensor (WetLabs). Calibration of the CTDs between years is discussed in Venables et al. (2013). Sampling for physicochemical variables, FCM abundances and phytoplankton pigments was conducted approximately twice weekly. Water samples were shielded from the light and processed as soon as possible in a temperaturecontrolled lab maintained at c.a. $0.5-1{ }^{\circ} \mathrm{C}$.

\section{Physicochemical variables}

Density, temperature, salinity and PAR were obtained from the CTD. Sampling was conducted when the study site was ice free and accessible by boat (i.e. no CTD casts were performed under sea ice). Euphotic zone depth $\left(Z_{\text {eu }}\right)$ was calculated as the depth at which PAR was $1 \%$ of surface $(1 \mathrm{~m})$ PAR. As an index to determine possible light limitation at the sampling depth, $Z_{\text {eu }}$ was divided by $15 \mathrm{~m}\left(Z_{\text {eu }} / 15 \mathrm{~m}\right)$, whereby a score $<1$ indicates possible light limitation (phytoplankton are below the euphotic zone) and $>1$ no (or reducing probability of) light limitation. Stratification was quantified as the potential energy required to homogenize the water column from the surface to $40 \mathrm{~m}$ depth $\left(\mathrm{J} \mathrm{m}^{-2}\right)$ according to Venables et al. (2013). MLD was defined as a $0.05 \mathrm{~kg} \mathrm{~m}^{-3}$ difference in density relative to the surface (Venables et al. 2013). Sea ice type and coverage (\%) was determined routinely every day in Ryder Bay by visual observation by Rothera base staff, with the Rothera records agreeing well with wider scale satellite-derived trends (see Venables et al. 2013). Definitions for ice type (as defined by the British Antarctic Survey) were as follows: fast ice is a solid sheet of ice attached to the land, pack ice is a large area of sea ice that is not land fast, brash ice is small fragments of floating ice, grease ice is a very thin layer of frazil ice (ice crystals formed in water that is too turbulent to freeze solid) and pancake ice is round pieces of newly formed ice (from grease ice). Discrete water samples $(6 \mathrm{~mL})$ for dissolved inorganic phosphate, nitrate, nitrite, and silicate, were gently filtered through 0.2- $\mu \mathrm{m}$ pore-size Supor membrane Acrodisk filters (25 mm diameter, Pall, Port Washington, NY 11050, USA). Ammonium samples were collected and analysed as in Clarke et al. (2008). Silicate samples were stored at $4{ }^{\circ} \mathrm{C}$ and those for nitrogen and phosphorus at $-20{ }^{\circ} \mathrm{C}$ until further analysis according to procedures described in detail by Bown et al. (2017).

\section{Phytoplankton data}

For phytoplankton enumeration (of single cells), fixed samples were counted during S1 and fresh (live) samples during S2. Technical problems with the flow cytometer during S1 prohibited live counts of phytoplankton abundances. No significant difference was found in phytoplankton population counts between live and fixed samples (Mann-Whitney Rank Sum Test: $p=0.24, n=44)$. For S1, $3.5 \mathrm{~mL}$ 
subsamples were fixed with $100 \mu \mathrm{L}$ formaldehyde-hexamine $(18 \% \mathrm{v} / \mathrm{v}: 10 \% \mathrm{w} / \mathrm{v})$ at $4{ }^{\circ} \mathrm{C}$ for $15-30 \mathrm{~min}$, after which they were snap-frozen in liquid nitrogen and stored at $-80{ }^{\circ} \mathrm{C}$ until analysis. Samples were analysed according to Marie et al. (1999) using a Becton-Dickinson FACSCalibur FCM equipped with an air-cooled Argon laser with an excitation wavelength of $488 \mathrm{~nm}(15 \mathrm{~mW})$ and the trigger was set on red fluorescence. Phytoplankton populations were distinguished using bivariate scatter plots of red Chlorophyll-a (Chl-a) autofluorescence versus side scatter. Cryptophytes were discriminated based on their orange phycoerythrin autofluorescence. The FCM data files were analysed using the freeware CYTOWIN (Vaulot 1989). No indications of chains or colonies were found in FCM cytograms.

During the summer months, approximately weekly size fractionations were performed to determine the average cell size of the different phytoplankton populations distinguished using FCM. A whole water sample $(5-10 \mathrm{~mL})$ was gently filtered through either a 50-, 20-, 10-, 8-, 5-, 3-, 2-, 1-, 0.65-, or $0.4-\mu \mathrm{m}$ pore-size filters. The filtrates were then analysed by FCM as described previously. Mean cell size was calculated as the size corresponding to a $50 \%$ retention of cells based on the fit of an S-shaped plot (i.e. number of cells retained versus the pore size; Veldhuis and Kraay 2004). Over the course of both seasons, a total of 10 phytoplankton populations were distinguished, referred to as Phyto I to Phyto X according to increasing average cell diameter (Table 1).

Vertical profiles (published in Bown et al. 2017; Rozema et al. 2017b) indicate that fluorescence-based Chl-a concentrations at $15 \mathrm{~m}$ were most often comparable to subsurface Chlorophyll maximum (SCM). For Chl-a concentration and taxonomic composition, 1-8 L of whole seawater was filtered over GF/F glass fibre filters (47 mm, Whatman, The Netherlands). Filters were wrapped in aluminium foil, snap-frozen in liquid nitrogen and stored at $-80^{\circ} \mathrm{C}$ until analysis. For the majority of samples, phytoplankton pigments were analysed by high performance liquid chromatography (HPLC) according to Brussaard et al. (2016). Three phytoplankton samples

Table 1 Average cell diameter (with standard deviation, $n=15$ ) of the different phytoplankton groups identified by flow cytometry

\begin{tabular}{lr}
\hline Name & \multicolumn{1}{c}{$\begin{array}{l}\text { Diameter } \\
(\mu \mathrm{m})\end{array}$} \\
\hline Phyto I & $0.9 \pm 0.1$ \\
Phyto II & $1.8 \pm 0.6$ \\
Phyto III & $3.1 \pm 0.5$ \\
Phyto IV & $4 \pm 0.6$ \\
Phyto V & $4.5 \pm 0.7$ \\
Phyto VI & $4.5 \pm 0.7$ \\
Phyto VII & $7.4 \pm 1.7$ \\
Phyto VIII & $8.1 \pm 1.8$ \\
Phyto IX & $11.5 \pm 3.0$ \\
Phyto X & $20.4 \pm 2.2$ \\
\hline
\end{tabular}

in $\mathrm{S} 1$ and 8 phytoplankton samples in S2 were analysed by HPLC according to Rozema et al. (2017a), as these samples were part of the BAS monitoring project. The pigment concentrations extracted and detected by the two separate approaches were not significantly different $(p<0.0001$; $R^{2}=0.99, n=39$ ) for natural samples collected in situ (Online Resource 1). In both cases, pigment quantification was performed using standards (DHI, Hørsholm, Denmark) for Chlorophyll $c_{3}$, Peridinin, 19'-Butanoyloxyfucoxanthin, Fucoxanthin, Neoxanthin, 19'-Hexa-fucoxanthin, Alloxanthin, Lutein, Chlorophyll $b$, Chl-a, and identified peaks were manually checked for quality assessment. Phytoplankton class abundances were calculated using pigment data from HPLC by CHEMTAX v1.95 (Mackey et al. 1996). This programme uses a factor analysis and the steepest decent algorithm to find the best fit based on a pigment ratio matrix. Six different taxonomic phytoplankton classes were chosen to represent the WAP marine ecosystem, identical to those used previously for the RaTS time series (Rozema et al. 2017a) and confirmed by microscopy observations (unpublished data): Prasinophyceae, Chlorophyceae, Dinophyceae, Cryptophyceae, Prymnesiophyceae and Bacillariophyceae (diatoms). Unfractionated pigment concentration data were sorted into two bins depending on season (S1 and S2). Additionally, size-fractionated samples were also binned per season. CHEMTAX was run 60 times per bin with randomized $( \pm 35 \%)$ pigment ratios to minimize the root mean square error (RMSE) using settings recommended in Kozlowski et al. (2011). The run with the lowest RMSE was deemed final with initial and final ratios shown in Online Resource 2.

Within each season (S1 and S2), four distinct periods were identified based on the temporal dynamics of Chl-a concentration: no bloom (NB) from 1 to 29 November, and bloom 1-3 (B1-3) from 30 November to 8/9 January, 9/10 January to $10 / 14$ February, and 11/15 February to 15 April, respectively.

In general size fractionation of whole water for pigment analysis was performed once a week during the summer months. Between 1 and $5 \mathrm{~L}$ of whole seawater was presieved through different filters (20 and $5 \mu \mathrm{m})$ and then filtered over a 47-mm GF/F glass fibre filter (Whatman, $0.7 \mu \mathrm{m}$ nominal pore size) to obtain size fractions $>20,5-20$ and $<5 \mu \mathrm{m}$. Filters were subsequently snap-frozen in liquid nitrogen wrapped in aluminium foil and stored at $-80{ }^{\circ} \mathrm{C}$ until analysis.

\section{Carbon conversion}

To allow for a better comparison between FCM and CHEMTAX data, phytoplankton abundances and taxonspecific Chl-a concentrations were converted to cellular carbon (C). The $\mathrm{C}$ content of each phytoplankton population identified by FCM (FCM-C) was estimated from 
the average cell diameter (assuming cells to be spherical)

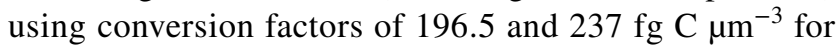
nano- and pico-sized phytoplankton populations, respectively (Garrison et al. 2000; Worden et al. 2004). Carbon conversion factors may vary, depending on taxonomy, cell size and growth-regulating factors such as light and nutrient availability (Geider 1987; Álvarez et al. 2017). Cell size variation was taken into account by using sizedependent conversion factors for the various FCM phytoplankton clusters (Phyto I-X). To accommodate for taxonomic variations in cellular Chl-a concentrations (Geider 1987; Álvarez et al. 2017), we used different conversion factors (also reflecting cell size) for the classified groups (e.g. diatoms and cryptophytes). Carbon estimates for the different phytoplankton taxonomic groups were thus obtained from taxon-specific Chl-a concentration multiplied by taxon-specific conversion factors according to Garibotti et al. (2003), with the exception of Dinophyceae for which an average of ratios by Llewellyn et al. (2005) and Agirbas et al. (2015) were used. Moreover, for the dominating diatoms and cryptophytes, it was possible to refine carbon estimates based on Chl-a (named ChlC) using published conversion factors specific for different biomass concentrations (according to Garibotti et al. 2003), i.e. low $<1$, medium $1-4$ and high $>4 \mu$ g Chl-a L ${ }^{-1}$ dominated by small-, nano- and micro-sized phytoplankton, respectively. The only exception was during B3 of S1, where the medium biomass $\mathrm{C}: \mathrm{Chl}-\mathrm{a}$ ratio was used due to the dominance of total Chl-a by nano-sized phytoplankton (Online Resource 4) despite high Chl-a concentrations. For the majority of both seasons, Chl-a cell ${ }^{-1}(\leq 20 \mu \mathrm{m})$ ranged between 0.1 and $0.8 \mathrm{pg}$.

The $\mathrm{C}$ to $\mathrm{Chl}$-a ratios used in this study originate from Garibotti et al. (2003; with reference to Montagnes and Franklin 2001 and Montagnes et al. 1994) who used different taxonomic groups and cell sizes with culture light conditions below light saturation $\left(50 \mu \mathrm{mol}\right.$ photons $\mathrm{m}^{-2}$ $\mathrm{s}^{-1}$ ), more representative of natural conditions. However, it is difficult to correct for potential seasonal variability of (natural variation in) carbon conversion factors (not already covered by us). Chl-a $(<20 \mu \mathrm{m})$ varied between 0.1 and $4.1 \mathrm{pg} \mathrm{cell}^{-1}$ and was within range of experimental values (Álvarez et al. 2017). Cellular Chl-a content was only higher (i.e. $>0.8 \mathrm{pg}^{\text {cell }}{ }^{-1}$ ) during the $\mathrm{B} 3$ bloom of S1 when PAR reduced to very low levels, indicating possible photoacclimation. However, increased Chl-a cell $^{-1}$ was most likely the result of a change in community composition as larger cells (from Phyto VI to Phyto IX) increasingly dominated Chl-a $(<20 \mu \mathrm{m})$. Furthermore, size fractionation on 13th March indicated that the average diameter of Phyto IX had also increased from 11 to $12-15 \mu \mathrm{m}$.

\section{Statistical analysis}

To check for potential differences in FCM abundances between fresh and fixed phytoplankton samples, a Mann-Whitney Rank Sum Test (SigmaPlot 14.0) was performed on 44 population counts from 8 samples spread over S2.

Canonical correspondence analysis (CCA) was performed on measured data using the $\mathrm{R}$ statistical software (R Development Core Team 2012) supplemented with Vegan (Oksanen et al. 2013). Data exploration was carried out according to the protocol described in Zuur et al. (2010). A combined forward-backward selection procedure was applied to select only those explanatory variables that contributed significantly to the CCA model, while removing non-significant terms. Significance was assessed by a permutation test, using the multivariate pseudo- $F$ value as the test statistic (Zuur et al. 2009). A total of 999 permutations were used to estimate $p$ values associated with the Pseudo- $F$ statistic. To identify and remove any collinearity from final models, variance inflation factors (VIF) were calculated. Sequentially, explanatory variables with the largest VIF were removed until all variables resulting in VIF $<10$ (Zuur et al. 2009). The environmental variables (after VIF selection) included as constraining variables in the multivariate analysis were temperature, salinity, PAR, MLD, $Z_{\mathrm{eu}} / 15 \mathrm{~m}$, stratification (Strat), phosphate, nitrate, silicate, wind speed and ice cover. Additionally, ice type (levels) and seasons (S1 and S2) were added as factors to see how they relate to phytoplankton abundance and taxonomic composition. PAR, MLD, $Z_{\mathrm{eu}} / 15 \mathrm{~m}$, phosphate and nitrate data were log transformed due to their non-linear relationship to total biomass, and to reduce the effects of outliers. CTD casts were absent for 13 phytoplankton abundance samples and 17 pigment samples from S1, and 9 from both sample types of S2. To overcome this limitation and permit data to be included into the CCA, the time series data (temperature, salinity, PAR, MLD, $Z_{\text {eu }} / 15 \mathrm{~m}$ and Strat) were linearly interpolated. For most of those samples (80\%), CTD casts were taken within 1 day (and often 1 day before and 1 day after) of biological samples and the remaining were taken within 2 days (apart from 1 sample taken 3 days apart). Five data points (spread evenly over the season) in S1 and 1 data point in $\mathrm{S} 2$ were missing nutrient data, and so interpolated data were also used for these 6 time points.

The analysis of biological variables consisted of phytoplankton abundance (FCM) and carbon biomass (converted from FCM), and pigment-based phytoplankton taxonomic community composition (in Chl-a) and taxonspecific carbon biomass (converted from Chl-a). Note that for Chl-a data, 'season' did not contribute significantly to the model, allowing for combined analysis of both 
seasons. For FCM data, season was a significant factor and subsequently $\mathrm{S} 1$ and $\mathrm{S} 2$ data sets were ran separately.

When interpreting CCA correlation triplots, arrow lengths represent the covariates and their correlation with the axes (CCA1 horizontal axis and CCA2 vertical axis). The correlation between response variables is reflected in the angles between lines, wherein, a small angle between two lines represents a high positive correlation, a $90^{\circ}$ angle represents no correlation and $180^{\circ}$ a strong negative correlation.

\section{Results}

\section{Physicochemical data}

At the beginning of November in S1, Ryder Bay was completely covered by fast ice which rapidly declined to $10 \%$ by mid-December (Fig. 2a). For the remainder of S1, brash ice was the main ice type with gradual declining cover (from 80 to $10 \%$ ) until mid-January after which it remained relatively low but with considerable variability. At the beginning of S2, grease ice was the dominated ice type (up to $100 \%$ cover), but ice cover rapidly changed to pack ice and declined in extent to $10 \%$ by 17 th November. Following this,
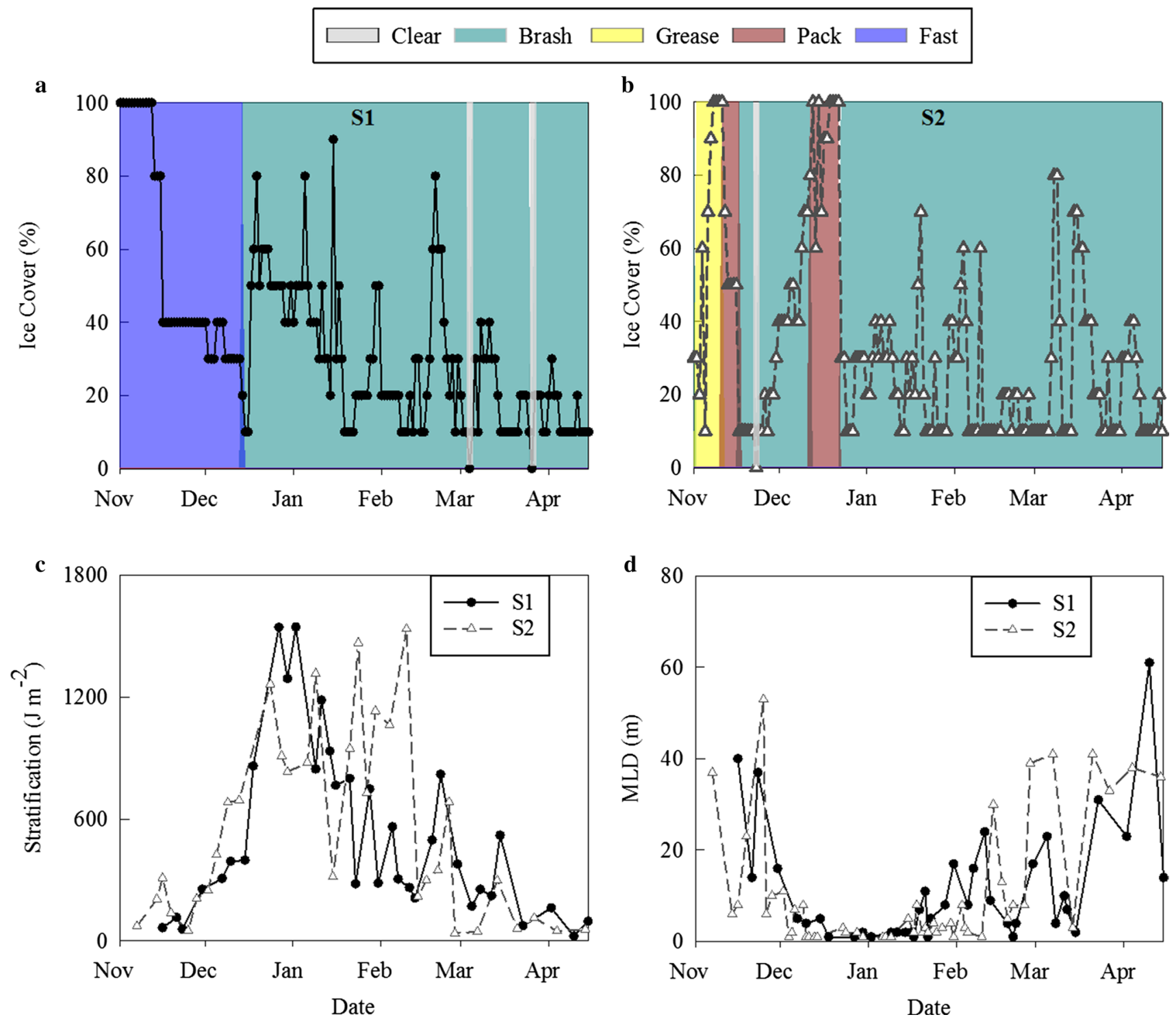

Fig. 2 Temporal dynamics of environmental conditions at the RaTS monitoring site (15 m depth) in Ryder Bay, Antarctica, from November to April during two consecutive years, S1 (circles, solid line) and

S2 (triangles, dotted line). Ice cover and ice type (Clear no ice, Brash Brash ice, Grease Grease ice, Pack Pack ice and Fast Fast ice) in a S1 and b S2, c vertical stratification, and $\mathbf{d}$ mixed layer depth (MLD) 
brash ice took over and cover increased to $100 \%$ (Fig. 2b). A short period of pack ice cover was observed in mid-December, returning into brash ice as ice cover rapidly declined during the second half of December. For the remainder of the season, brash ice remained generally low but variable (10-80\%).

Stratification increased steadily at the beginning of December in both seasons (Fig. 2c) accompanied by a shallowing of the MLD (Fig. 2d). Stratification peaked at the end of December (1544 in S1 and $1264 \mathrm{~J} \mathrm{~m}^{-2}$ in S2) and then declined during the first half of January in both seasons. In S2, stratification increased again and remained high until 10th February. This difference in stratification between the two seasons was apparent in MLD which was deeper in S1 at $16 \pm 8 \mathrm{~m}(n=3)$ compared to $2 \pm 1 \mathrm{~m}(n=3)$ during the same period of S2. Stratification levels were weak for both seasons in March and April, and MLD were relatively high ranging from 20 to $40 \mathrm{~m}$.

In both seasons, seawater temperature steadily increased from $-1.7{ }^{\circ} \mathrm{C}$ in November to $0{ }^{\circ} \mathrm{C}$ during early January
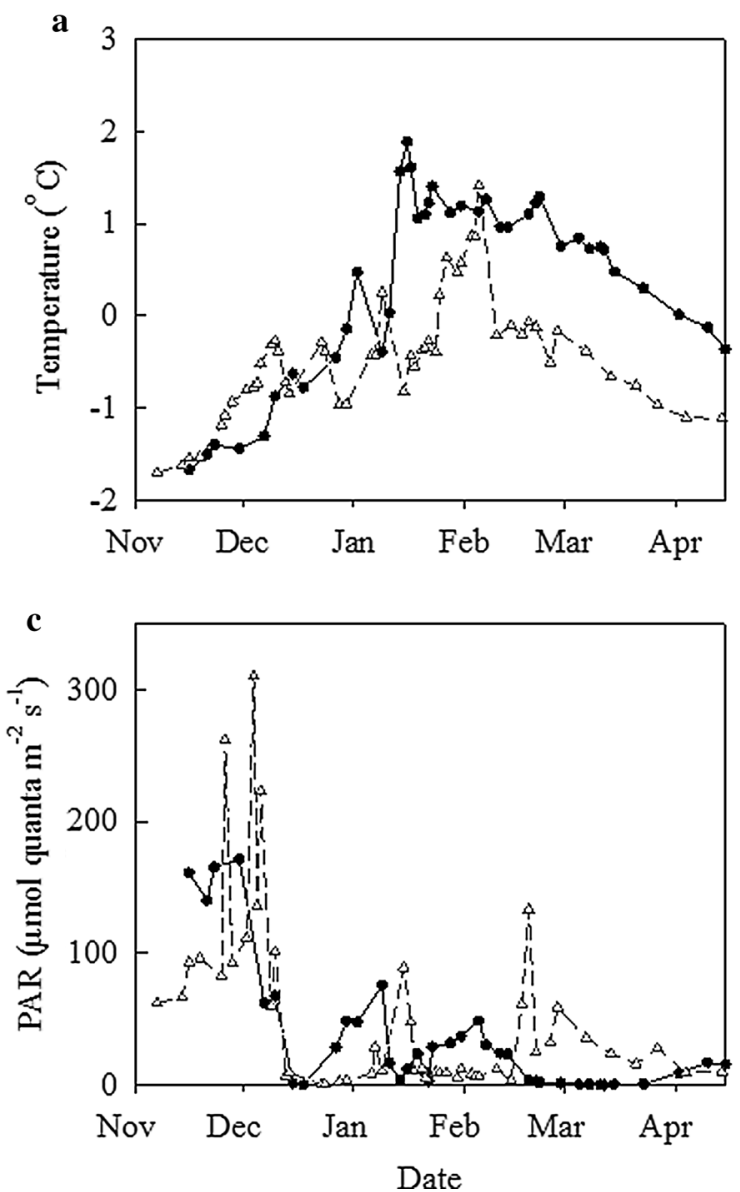

Fig. 3 Time series of a temperature, b salinity, c photosynthetic active radiation (PAR) and $\mathbf{d}$ the index of light limitation $\left(Z_{\mathrm{eu}} / 15 \mathrm{~m}\right)$, sampled at $15 \mathrm{~m}$ at RaTS in Ryder Bay during two consecutive years,
(Fig. 3a). Temperature during S1 peaked at $1.9^{\circ} \mathrm{C}$ on 16th January and remained around $1.2{ }^{\circ} \mathrm{C}$ for 1 month before gradually declining to below $0{ }^{\circ} \mathrm{C}$ in April. In S2, seawater temperature peaked later in the season $\left(1.4^{\circ} \mathrm{C}\right.$ on 5 th February) and declined to $<0{ }^{\circ} \mathrm{C}$ in early February, followed by a gradual decrease to around $-1.1{ }^{\circ} \mathrm{C}$ in April. Compared to $\mathrm{S} 1$, average temperature during $\mathrm{S} 2$ was $\sim 2.5$ fold lower $\left(0.36 \pm 1\right.$ vs. $-0.45 \pm 0.6{ }^{\circ} \mathrm{C}, n=39$ and 50 , respectively), with the strongest difference during bloom period B2 $\left(1.09 \pm 0.62\right.$ vs. $0.09 \pm 0.63{ }^{\circ} \mathrm{C}, n=13$ and 16 , respectively) and B3 (half February to April; $0.64 \pm 0.49$ vs. $-0.55 \pm 0.40{ }^{\circ} \mathrm{C}, n=15$ and 11 , respectively). Salinity gradually declined until January during S1 (Fig. 3b), whereas in S2, a rapid drop was observed during January, and values remained low for 3 weeks before stabilising at $\sim 33.0 \mathrm{psu}$ by March, slightly lower than the salinity of 33.2 psu in S1 over this period. PAR levels were the highest at the start of both seasons (Fig. 3c), declining thereafter to potentially growth-limiting levels (as indicated by $Z_{\text {eu }} / 15 \mathrm{~m}$; Fig. 3d) and reaching values as low as $0.3-0.4 \mu \mathrm{mol}$ quanta $\mathrm{m}^{-2}$

b
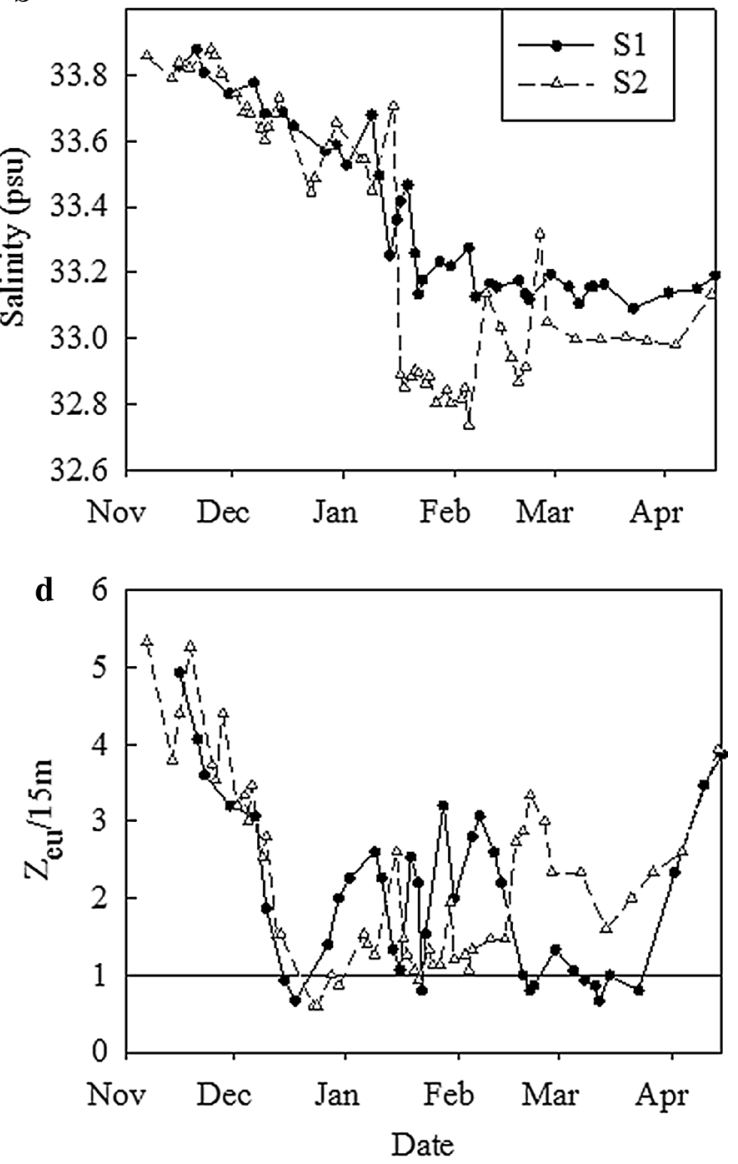

S1 (circles, solid line) and S2 (triangles, dotted line). The reference line in subplot (d) indicates potential light limitation 
$\mathrm{s}^{-1}$ by the second half of December. During the B2 bloom period of S2, PAR was generally low $(17 \pm 23 \mu \mathrm{mol}$ quanta $\left.\mathrm{m}^{-2} \mathrm{~s}^{-1}, n=15\right)$ and had a higher potential for light limitation compared to the same period in S1. Conversely, during the bloom period B3 of S1, PAR levels $(<3 \mu$ mol quanta $\mathrm{m}^{-2} \mathrm{~s}^{-1}$ ) were much lower compared to $\mathrm{S} 2$.

Phosphate and nitrate in S1 were drawn down from concentrations of 1.7 and $28 \mu \mathrm{M}$ on 8 th Dec to 0.17 and $1.3 \mu \mathrm{M}$, respectively, at the start of January, before rising again until mid-February (Online Resource 3). In S2, the initial drawdowns of phosphate and nitrate were more gradual and variable than S1, lasting until the beginning of February and reaching 0.04 and $0.03 \mu \mathrm{M}$, respectively. A second large drawdown of phosphate was observed during S1, declining to $0.06 \mu \mathrm{M}$ on 12th March. Ammonium concentrations were initially low in both seasons $(\sim 0.35 \mu \mathrm{M})$ and increased to $5 \mu \mathrm{M}$ on 5th February in $\mathrm{S} 1$ and $2.6 \mu \mathrm{M}$ on 17 th February in S2 (Online Resource 3). Silicate concentrations remained replete over the observation period of both seasons (Online Resource 3), as were concentrations of dissolved iron (DFe, Bown et al. 2017).

\section{Chlorophyll-a and taxonomic groups}

The mean Chl-a concentration in $\mathrm{S} 1(4.3 \pm 4.4 \mu \mathrm{g} \mathrm{L}-1$, $n=51)$ was 1.6 -fold higher than in $\mathrm{S} 2\left(2.7 \pm 2.2 \mu \mathrm{g} \mathrm{L}{ }^{-1}\right.$, $n=50$, Fig. 4). This was due to the S1 phytoplankton blooms (i.e. peaks in Chl-a) during bloom periods B1 and B3 (12.3 and $16.1 \mu \mathrm{g} \mathrm{Chl-a} \mathrm{L}{ }^{-1}$, respectively). In contrast, the B2 period in S2 displayed a higher mean Chl-a concentration than that in S1, i.e. $4.6 \pm 1.7$ and $2.0 \pm 1.5 \mu \mathrm{g} \mathrm{L}^{-1}, n=17$ and 16, respectively. Diatoms (Bacillariophyceae) often dominated total Chl-a both during S1 and S2 (Fig. 4c, d), but at the start of S2 (NB period), Prymnesiophyceae and

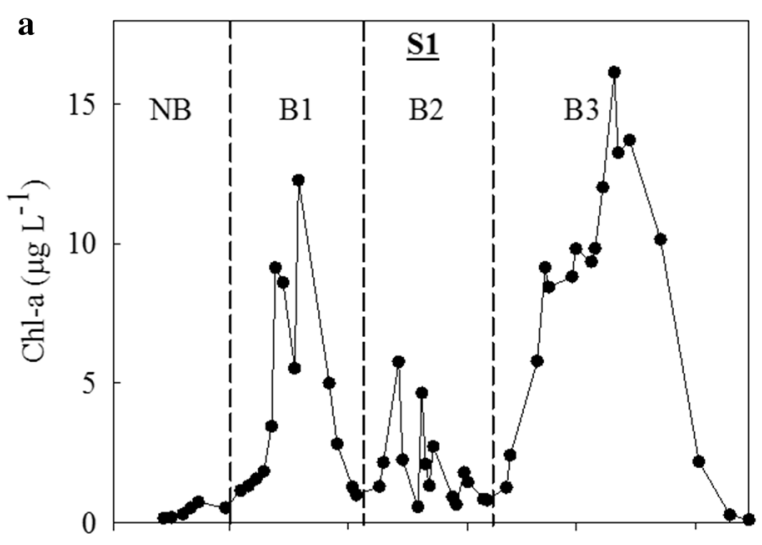

b
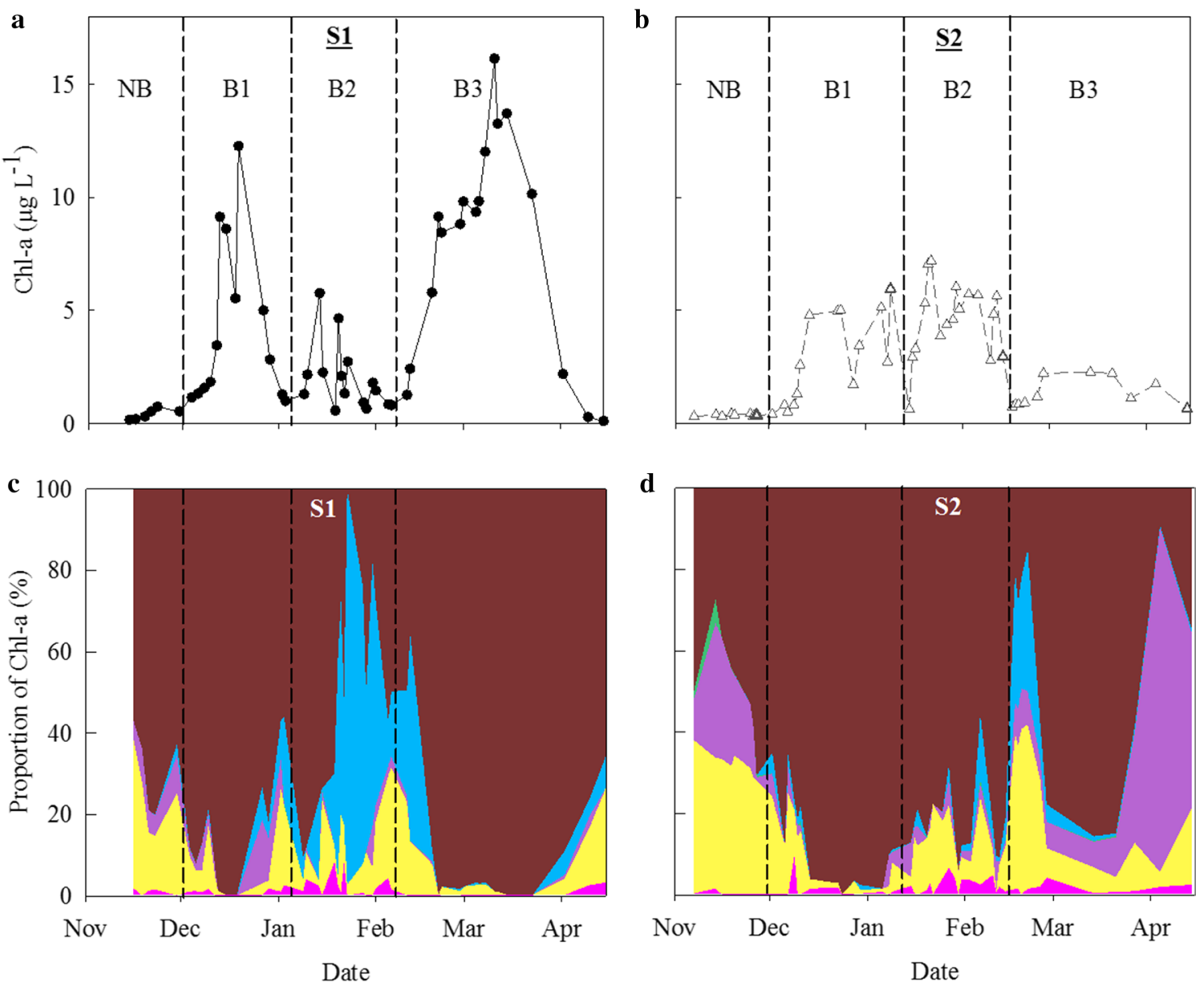

d

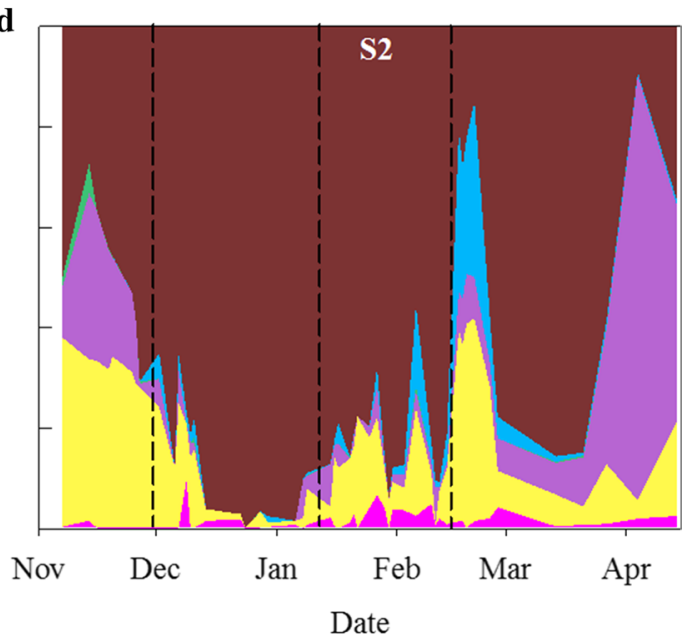

\begin{tabular}{|lll|}
\hline Diatoms & Chlorophyceae & Prymnesiophyceae \\
Cryptophyceae & Prasinophyceae & Dinophyceae
\end{tabular}

Fig. 4 Seasonal dynamics of total Chl-a concentration for a S1 and b S2. The relative proportions of each taxonomic group (identified through CHEMTAX) are shown over $\mathbf{c}$ S1 and $\mathbf{d}$ S2. Note: vertical dotted lines separate bloom periods NB and B1-3 
Prasinophyceae both dominated, and during B2 in S1, Cryptophyceae contributed most to total Chl-a concentration. Furthermore, at the start of B3 (second half of February) for both S1 and S2 the Cryptophyceae and Prymnesiophyceae co-dominated, while towards the end of B3 in S2, Prasinophyceae were most important. Contributions to Chl-a by Chlorophyceae and Dinophyceae were marginal over both seasons of this study.

Size-fractionated Chl-a shows that initially during the NB period when total Chl-a concentrations were still low (Fig. 4), the phytoplankton community was mostly $<20 \mu \mathrm{m}$ (Online Resource 4). Temporal Chl-a size fraction dynamics in $\mathrm{S} 1$ revealed a shift from larger-sized $(>20 \mu \mathrm{m})$ phytoplankton during the first bloom period B1 to smaller-sized phytoplankton during the remainder of the season (up to $89 \%$ of total Chl-a in B3; Online Resource 4a). In contrast, relatively smaller $(<20 \mu \mathrm{m})$ cells contributed most to phytoplankton biomass during the initial increase during B1 in S2 and larger cells dominating during B2 (Online Resource 4b). Taxonomic analysis of fractionated $\mathrm{Chl}$-a revealed that diatoms and Cryptophyceae were present in all the three size fractions. Prymnesiophyceae were present largely in the $<5 \mu \mathrm{m}$ fraction but were also observed in the $>20 \mu \mathrm{m}$ fraction, during March (B3) in S1 and late January to beginning of February in S2, presumably indicative for $P$. antarctica colonies (confirmed by light microscopy, data not shown).

Canonical correspondence analysis (CCA) was used to investigate the relationship between taxonomic composition (in Chl-a concentration) and the environmental variables with both $\mathrm{S} 1$ and $\mathrm{S} 2$ combined. The eigenvalues (obtained from the model output; Online Resource 5) indicated that the main environmental variables contributing to the formation of the axes explained $35 \%$ of total variation in the dataset (23 and $11 \%$ for first and second axes, respectively). These variables were temperature $(p<0.001, n=101), Z_{\mathrm{eu}} / 15 \mathrm{~m}$ $(p<0.001, n=101)$, salinity $(p=0.058, n=101)$, phosphate $(p=0.005, n=101)$ and nitrate $(p=0.039, n=101$, Fig. 5a). Overall, higher concentrations of Cryptophyceae were associated with high temperature $\left(>1{ }^{\circ} \mathrm{C}\right)$ and Prymnesiophyceae with relatively high $Z_{\text {eu }} / 15 \mathrm{~m}$ and low salinity. More specifically, the B2 data points in S1 clustered with high temperature and Cryptophyceae Chl-a, which were both highest during this period.

\section{Phytoplankton abundance (and taxonomy)}

The 10 phytoplankton clusters distinguished by FCM (Fig. 6) could be partially characterized (taxonomically). Temporal dynamics of Phyto III matched well with the dynamics of Prymnesiophyceae and light microscopy confirmed co-occurrence of $P$. antarctica single cells at times of high Phyto III abundances. Phyto III cell size (range 2-5 $\mu \mathrm{m}$ in diameter) corresponds to that of solitary P. antarctica cells (between 2 and $6 \mu \mathrm{m}$, Schoemann et al. 2005; Lee et al. 2016). Phyto IV dynamics compared well to Cryptophyceae Chl-a $(<20 \mu \mathrm{m}$, Online Resource 6) and was identified as a cryptophyte group based on high orange (phycoerythrin) autofluorescence (Li and Dickie 2001) in combination with microscopic identification during times of high abundance. Phyto V-X are most likely diatoms, based on the good comparison of relative carbon contribution of individual phytoplankton groups with CHEMTAX analysis of specific Chl-a size fractions (at times when large group-specific carbon contributions were observed). The picoeukaryotes (Phyto I and II) could not be classified due to their small cell size and limited contribution to FCM-C.

Similar to the average Chl-a concentration, mean phytoplankton abundance in $\mathrm{S} 1$ was higher than that in $\mathrm{S} 2$ $\left(5.5 \pm 3.0\right.$ vs. $3.7 \pm 2.2 \times 10^{3}$ cells $\mathrm{mL}^{-1}, n=40$ and 51 , respectively, Online Resource 7). Overall, the contribution of nano-sized phytoplankton (Phyto IV-X) was 1.5 times higher in $\mathrm{S} 1$ compared to $\mathrm{S} 2(53 \pm 24$ and $35 \pm 16 \%, n=40$ and 51, respectively), with Phyto IV, VI and IX dominating in $\mathrm{S} 1(13 \pm 17,24 \pm 16$ and $9 \pm 16 \%, n=40$, respectively) and Phyto V in S2 $(17 \pm 13 \%, n=51)$. All 10 phytoplankton clusters distinguished by FCM showed strong temporal dynamics with distinct differences between seasons (Fig. 6). At the start of the season during the NB period, the picoeukaryotic phytoplankton Phyto I and II were most abundant in $\mathrm{S} 1(45 \pm 4 \%$ and $22 \pm 3 \%, n=3$; Fig. $6 \mathrm{a}-\mathrm{c})$ and equally abundant to Phaeocystis Phyto III in S2 $(25 \pm 20,26 \pm 13$, and $25 \pm 14 \%$, respectively, $n=5$; Online Resource 8 ). Phyto I-III persisted during B1 in S1 $(24 \pm 19,31 \pm 11$ and $15 \pm 8 \%$, respectively, $n=9$ ), while diatom Phyto $\mathrm{V}$ bloomed during this period in $\mathrm{S} 2(30 \pm 10 \%, n=15$; Fig. 6e). Phyto IX (diatom) became also abundant during B1 of both seasons, contributing up to $18 \%$ in S1 and $45 \%$ in S2 (Fig. 6i and Online Resource 8). The B2 period of $\mathrm{S} 1$ was dominated by cryptophytes (Phyto IV $26 \pm 21 \%, n=16$; Fig. $6 \mathrm{~d}$ and Online Resource 7) and diatom Phyto VI ( $26 \pm 14 \%, n=16$; Fig. 6f), whereas Phaeocystis Phyto III and diatom Phyto V had the largest share in S2 $(51 \pm 14 \%$ and $16 \pm 7 \%$, respectively, $n=17$; Fig. 6c, e). During the initial stage of the large phytoplankton bloom in B3 of S1 (Fig. 4a), P. antarctica and diatom group Phyto VI were most abundant (contributing up to 23 and $56 \%$ of total abundances, respectively; Fig. 6c, f, Online Resource 8). The larger diatom group Phyto IX $(11.5 \pm 3 \mu \mathrm{m}, n=15)$ succeeded, making up to $64 \%$ of total abundance (Fig. 6i). Unlike S1, total phytoplankton abundances during B3 in S2 were relatively low (mean 5.1 \pm 3.4 and $1.9 \pm 1.2 \times 10^{3} \mathrm{~mL}^{-1}, n=40$ and 51 , respectively) and mostly dominated by Phyto III $(44 \pm 24 \%, n=51)$.

The CCA of FCM abundances revealed that the models shown in Fig. 5b, c explained $66 \%$ of the variation in the dataset of S1 (33\% and $25 \%$ by first two axes) and $71 \%$ of 
a

Chl-a

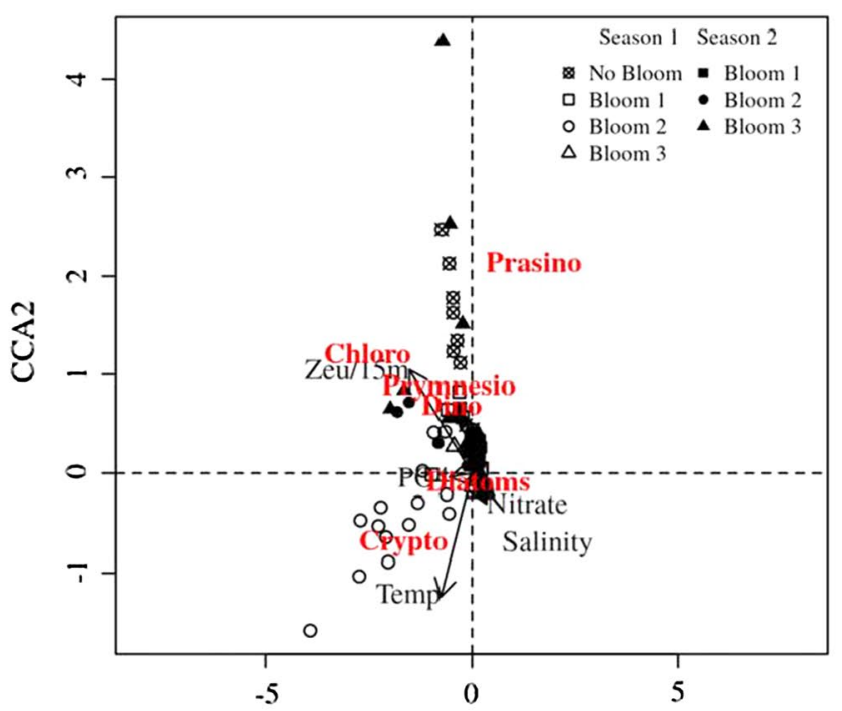

c

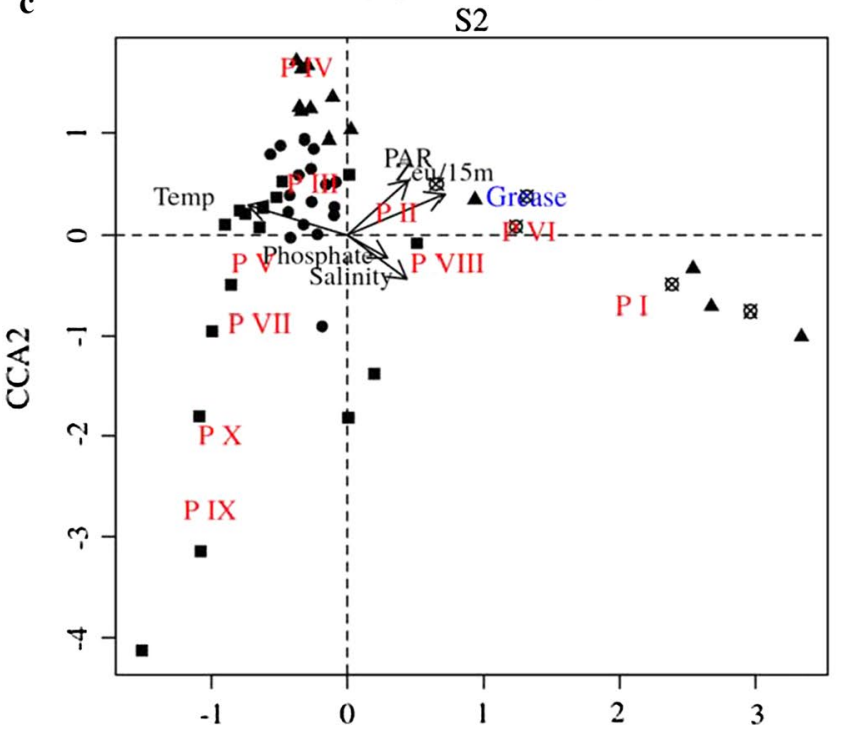

c

Fig. 5 Canonical correspondence analysis (CCA) of phytoplankton community composition (in red) in relation to environmental variables (in black). Ice type is represented in the CCA (in blue) where Fast Fast ice, Brash Brash ice etc. Subplots represent the community in terms of a Chl-a (with S1 and S2 combined), b FCM abundance in $\mathrm{S} 1$ and $\mathbf{c}$ FCM abundance in S2. Symbol shape represents bloom

S2 (35 and 22\% by first two axes explained). Contributing to the formation of both axes during both seasons were ice type (S1 $p<0.001, n=40 ; \mathrm{S} 2 p=0.010, n=51$ ), temperature (S1 $p<0.001, n=40$; S2 $p<0.001, n=51)$, PAR (S1 $p<0.001$, $n=40 ; \mathrm{S} 2 p=0.008, n=51)$ and salinity (S1 $p<0.001$, $n=40 ; \mathrm{S} 2 p<0.001, n=51$ ), followed by phosphate (S1 $p<0.001, n=40$; S2 $p<0.001, n=51)$, and also for S1 nitrate ( $\mathrm{S} 1 p<0.001, n=40)$ and $\mathrm{S} 2 Z_{\mathrm{eu}} / 15 \mathrm{~m}(\mathrm{~S} 2 p<0.001$, $n=51$ ). Phyto I, II, VIII and X in S1 were associated with

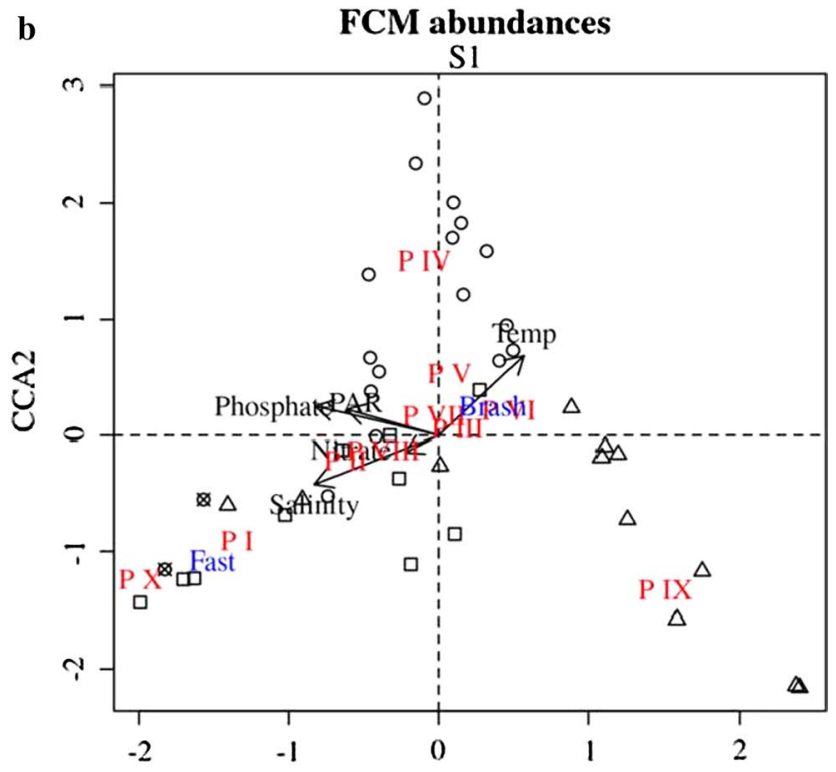

periods: no bloom (NB) and bloom 1-3 (B1-3), open symbols representing S1 bloom 1-3 and filled symbols S2 bloom 1-3. Abbreviations of response variables are as follows: Cryp Cryptophyceae, Chlo Chlorophyceae, Prymn Prymnesiophyceae, Pras Prasinophyceae, Dino Dinophyceae, $P I-X$ Phytoplankton groups I-X. (Color figure online)

fast ice, as well as high salinity and low temperature. In S2, ice type (grease ice) was again associated with Phyto I and II, but also diatoms Phyto VI and VIII. Additionally (in S2), these phytoplankton clusters were associated with high salinity, PAR, $Z_{\text {eu }} / 15 \mathrm{~m}$ and phosphate. Phyto $\mathrm{X}$ in S2 was, together with other diatom clusters, Phyto V, VII and IX, associated with low PAR and low $Z_{\text {eu }} / 15 \mathrm{~m}$ conditions (Fig. 5c). Phyto IX in S1 was also correlated with low PAR and low phosphate concentrations, the predominant 
Fig. 6 Temporal dynamics of phytoplankton abundance over S1 (circles, solid line) and S2 (triangles, dotted line) whereby 10 distinct populations could be discriminated (using FCM): Phyto I-X (a-f). Note the different scales for abundances

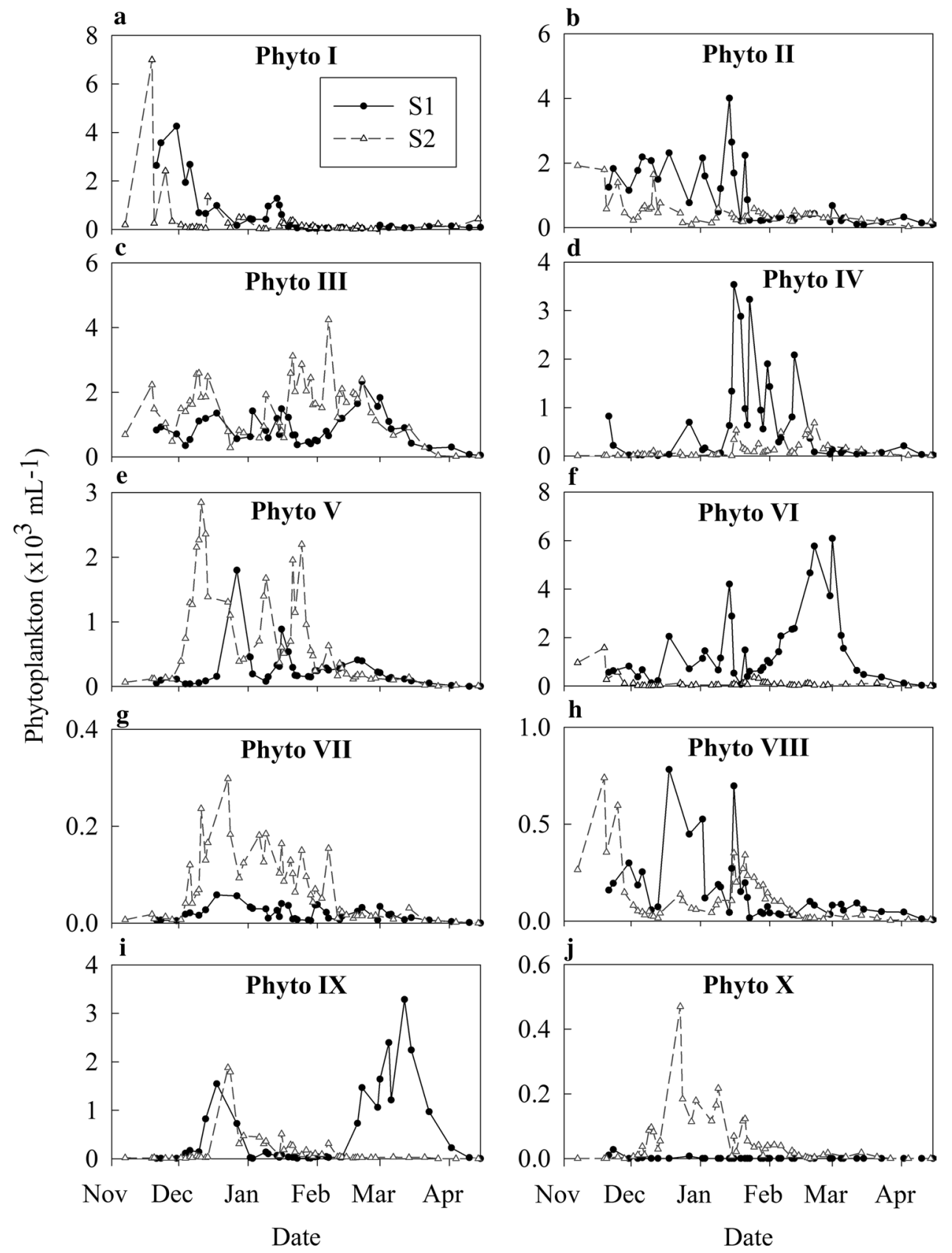

environmental conditions during B3 in S1 (open triangles in Fig. 5b). Phyto IV (cryptophytes) in S1 was associated with high temperature, PAR and phosphate conditions (as for example found during B2 in S1; open circles Fig. 5b). In S2, these cryptophytes, as well as Phaeocystis (Phyto III), were similarly associated with high temperature and high PAR, but also low salinity and low phosphate (Fig. 5c).

\section{Phytoplankton carbon}

Considering the variation in cell sizes, we converted both phytoplankton abundances and Chl-a to cellular carbon for a more detailed comparison (Fig. 7a, b). As to be expected, the larger-sized phytoplankton clusters made up most of the cellular carbon (FCM-C) during both seasons (Fig. 8a, b), despite occasional low abundances (e.g. diatom Phyto $\mathrm{X}$ during March in S2; Fig. 6j). Due to size restrictions of FCM analysis (reliable acquisition is limited to cells around $20 \mu \mathrm{m}$ in diameter, based on the laser beam width), we focused our comparison of FCM-C with CHEMTAX-C on the $\leq 20 \mu \mathrm{m}$ size fraction. The $<5 \mu \mathrm{m}$ and 5-20 $\mu \mathrm{m}$ fractions showed generally good agreement for both seasons (Fig. 7c-f). The few discrepancies were related to FCM population-specific variations in cell diameter over time, whereby the actual 

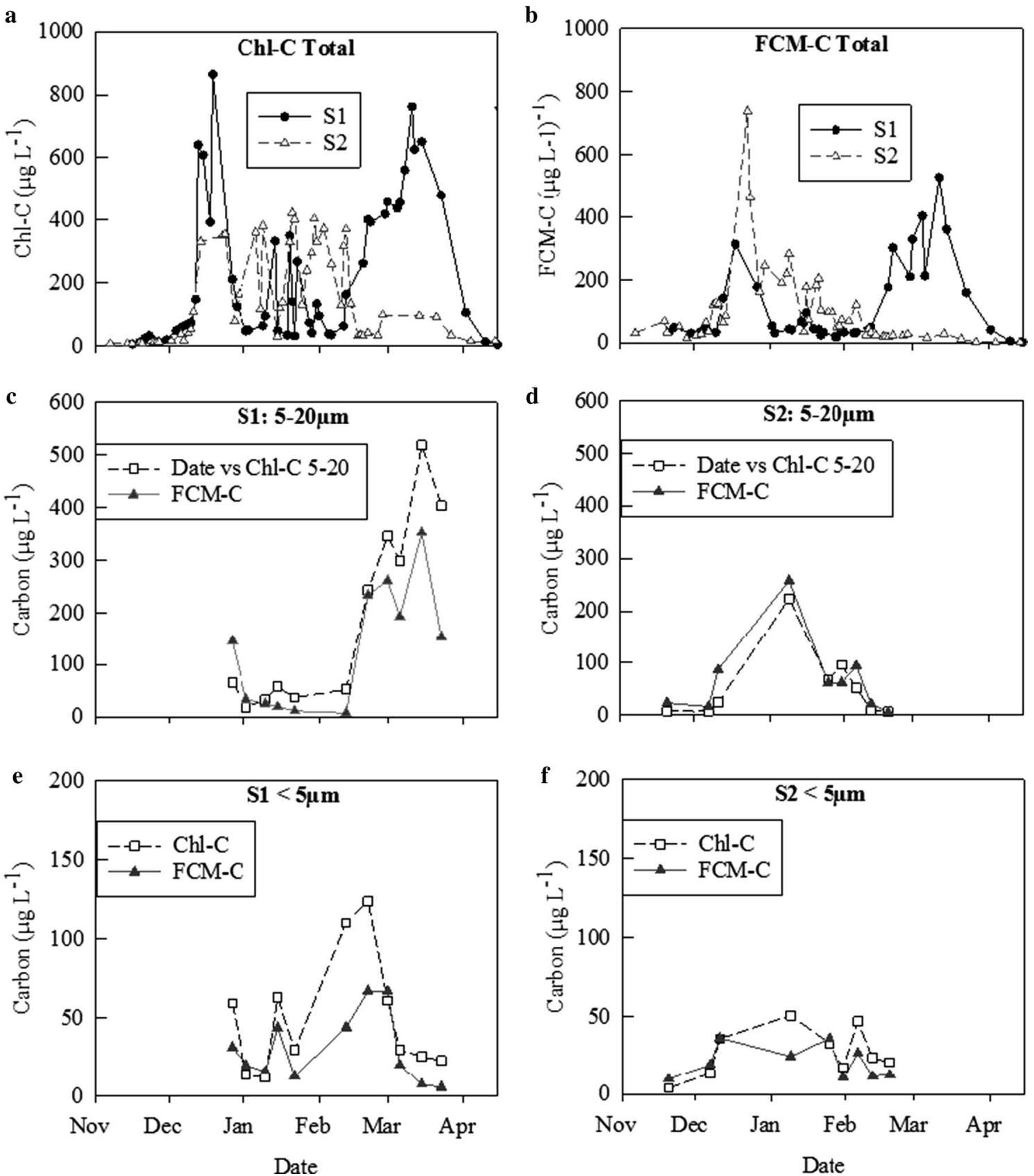

Fig. 7 Time series of phytoplankton cellular carbon where: a represents total Chl-C and b total FCM-C, over S1 and S2. Fractionated $\mathrm{Chl}-\mathrm{C}$ is compared to FCM-C for the 5-20 $\mu \mathrm{m}$ fraction in $\mathbf{c}$ over $\mathrm{S} 1$

diameter of the dominant population, at that specific moment in time, was larger than the mean. A larger diameter (compared to the mean) combined with high abundance resulted in observably lower FCM carbon estimations when using mean cell size compared to the actual cell size at the time.

When taxonomic composition was expressed in Chl-C, $42 \%$ of variation was explained by the CCA model shown in Fig. $9 \mathrm{a}$ (40 and $1 \%$ by first 2 axes). In particular, Cryptophyceae were associated with the main environmental

and $\mathbf{d}$ over S2, while the $<5 \mu \mathrm{m}$ fraction is shown in $\mathbf{e}$ over $\mathrm{S} 1$ and $\mathbf{f}$ over S2. Note the different $Y$ axis scales

variables contributing to the formation of the two primary axes, i.e. higher temperature $(p<0.001, n=101)$, a reduced potential for light limitation (higher $Z_{\mathrm{eu}} / 15 \mathrm{~m}, p<0.001$, $n=101)$ and higher phosphate concentrations ( $p=0.002$, $n=101$ ). The CCA based on FCM-C in S1 showed similar clear clustering of cryptophytes Phyto IV with B2 environmental data points when temperature was highest (Fig. 9b). Besides temperature, Phyto IV also correlated with higher PAR in both S1 and S2 (Fig. 9b, c). The FCM-C-based CCA 


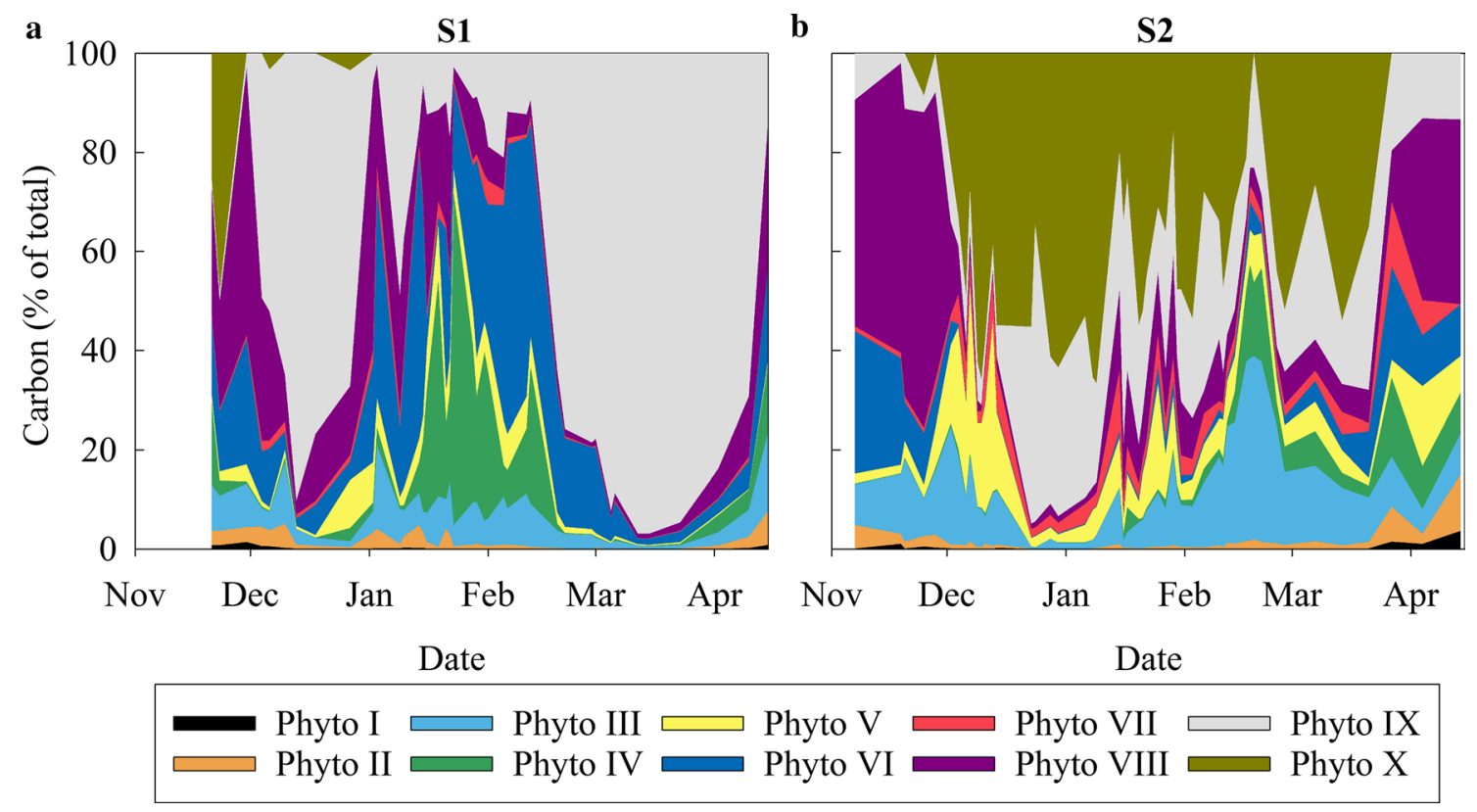

Fig. 8 Seasonal dynamics in the relative contribution of each phytoplankton group to total FCM-C over: a S1 and b S2

showed that the prymnesiophytes and Phyto III also related strongly to higher PAR in $\mathrm{S} 1$ and high PAR, high $Z_{\mathrm{eu}} / 15 \mathrm{~m}$, and relatively low salinity in $\mathrm{S} 2$. The different diatoms did not display similar relationships based on FCM-C. Phyto V, VII, and VIII were all associated with high PAR in S1, and ice type especially in S2 (Phyto VI and VIII with grease and Phyto V and VII with pack ice; Fig. 9b, c). With the FCMC-based CCA model, $42 \%$ of variation in the dataset of S1 was explained by the environmental variables with the first 2 axes explaining 31 and 9\%, respectively. During S2, the CCA model explained even more, i.e. $65 \%$ of total variation in FCM-C with the first two axes explaining 40 and $16 \%$ of variation, respectively.

\section{Discussion}

\section{Ice type and early season phytoplankton dynamics}

Previous studies have shown that melting sea ice can seed the surrounding waters with phytoplankton cells (e.g. Garrison et al. 1987; Arrigo 2003; Jin et al. 2007), however, there is currently a limited understanding how ice type can structure phytoplankton community dynamics. Our data indicate that ice type (fast, grease, pack or brash ice) was an important factor structuring the pre-bloom phytoplankton community and the cell size structure of the early summer phytoplankton bloom community (Figs. 5, 9). During the pre-season (August to October, data not shown) ice cover was similar between the 2 years; however, the pre-bloom phytoplankton community of S1 was associated with fast ice, while grease ice was important during S2 (Figs. 5, 8). Ice type rather than ice cover seemed the most influential factor establishing the seed population for the productive season. The initial summer phytoplankton bloom (B1) during both seasons (Fig. 4) coincided with the period of greatest increase in vertical stratification (Eveleth et al. 2017). Nevertheless, decreasing fast ice cover in S1 (Fig. 2) coincided with a bloom of large diatoms $(>20 \mu \mathrm{m})$, while in $\mathrm{S} 2$, the B1 bloom consisted of diatoms mostly $\leq 20 \mu \mathrm{m}$ (Online Resource 4) which corresponded to an increase in brash ice (turning into pack ice). Distinct differences in the pigment to Chl-a ratios during S1 and S2 are indicative of dissimilar phytoplankton seeding from ice. The relatively low ratios of Chl-c2, fucoxanthin and diadinoxanthin + diatoxanthin [Dd + Dt] to Chl-a (0.1, 0.5 and 0.1, respectively; Online Resource 9a) during B1 in S1 indicate that the larger diatoms were the result of marginal ice edge algal blooms (Rodriguez et al. 2002; Wulff and Wängberg 2004; Hashihama et al. 2008; Kozlowski et al. 2011). In contrast, the higher Chl-c2 and fucoxanthin to Chl-a ratios (1.4 and 2.5, respectively, Online Resource 9b) during the initial phytoplankton biomass rise in S2 suggests that the smaller-sized diatoms had higher light absorption efficiencies in the blue spectrum (characteristic of ice-associated algae; Robinson et al. 1995). Furthermore, the higher Dd+Dt to Chl-a ratio of 1.2 indicates these diatoms were recently released from the photo-protective effect of ice and became exposed to 
a

Chl-C

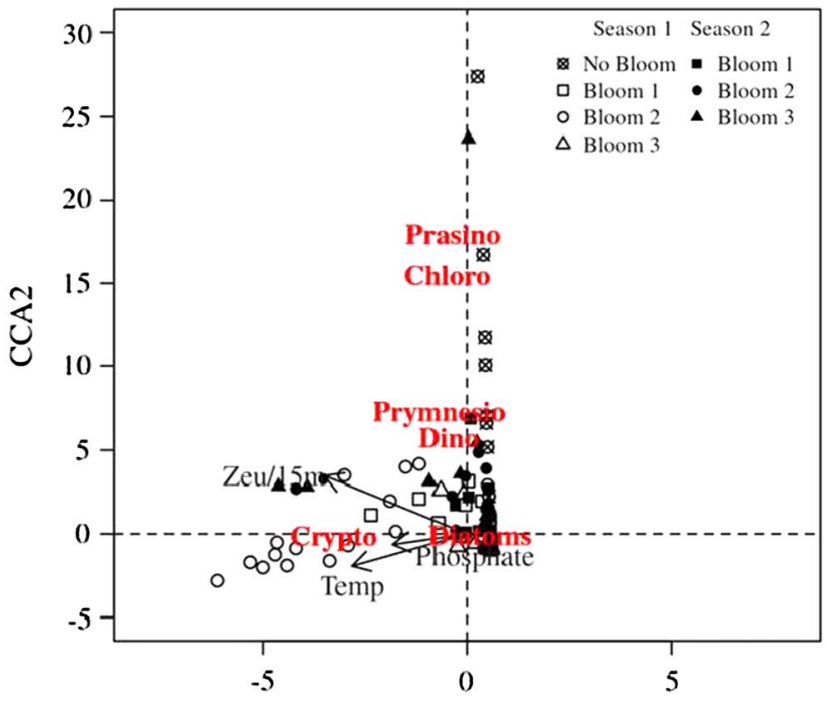

c

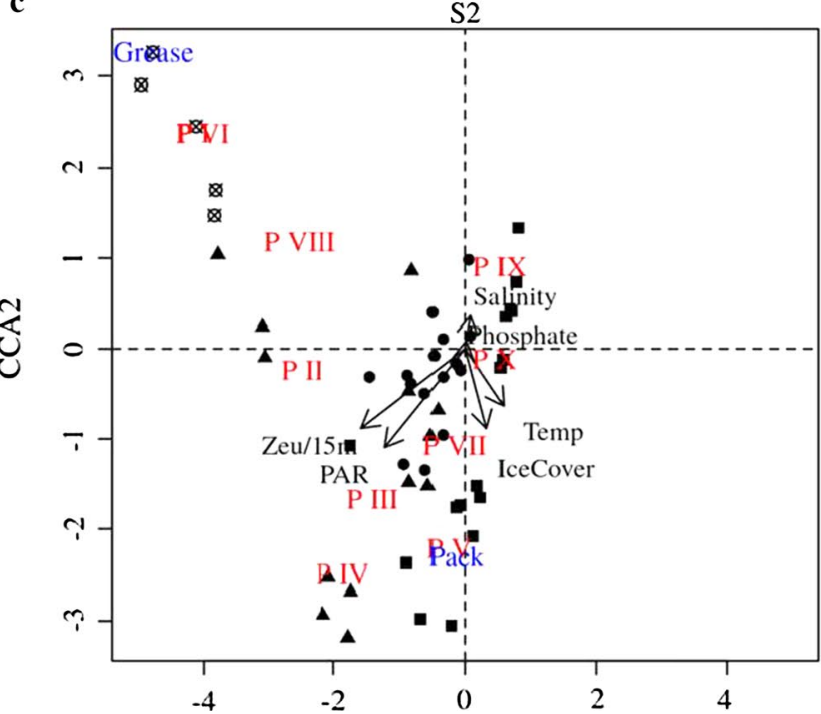

b

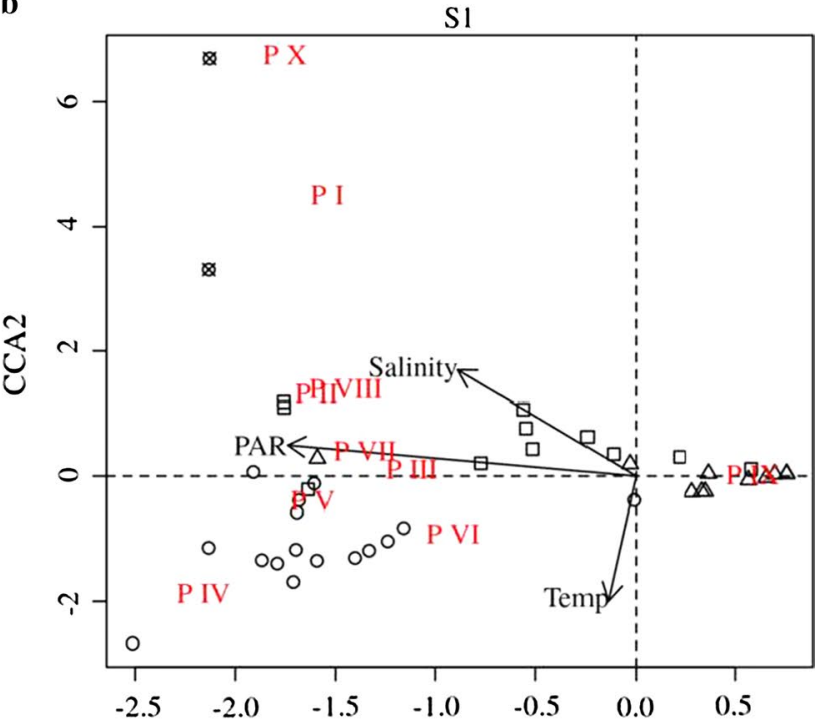

Fig. 9 Canonical Correspondence Analysis (CCA) of phytoplankton community composition (in red) in relation to environmental variables (in black). Ice type is represented in the CCA (in blue) where Fast Fast ice, Brash Brash ice etc. Subplots represent the community in terms of a Chl-C concentration (with S1 and S2 combined), b FCM-C in S1 and c FCM-C in S2. Symbol shape represents bloom periods: No bloom (NB) and bloom 1-3 (B1-3), open symbols rep-

high surface light (Robinson et al. 1997; Petrou et al. 2011; Van De Poll et al. 2011).

\section{Summer phytoplankton dynamics}

The increased Chl-a concentrations during B1 in both seasons coincided with rapid declines in PAR (to potentially limiting levels; Fig. 3d) most likely due to the increasing light attenuation (community shading). The low light resenting S1 bloom 1-3 and filled symbols S2 bloom 1-3. Abbreviations of response variables are as follows: Cryp Cryptophyceae, Chlo Chlorophyceae, Prymn Prymnesiophyceae, Pras Prasinophyceae, Dino Dinophyceae, $P$ I-X Phytoplankton groups I-X. Note: in FCM-C S2 (subplot c), Phyto groups I and VI are located directly on top of each other. (Color figure online)

availability was associated with a shift towards smaller-sized diatoms (Timmermans et al. 2001), particularly Phyto IX (Fig. 6i). Whereas additional nutrient depletion may have caused the decline of the B1 bloom in S1, a short-lived moderate mixing event end of December of S2 (Online Resource 10) resulted in elevated nutrient concentrations and sustained phytoplankton standing stock during the low salinity-induced highly stratified (Gonçalves-Araujo et al. 2015; Rozema et al. 2017b) B2 period (Online Resource 
3, Figs. 3b and 2c). Subsequently, rapid nutrient drawdown may have caused growth-limiting conditions during early February $(0.04$ and $0.03 \mu \mathrm{M}$, for phosphate and nitrate respectively); however, a mixing event around that time (represented here for example by increased salinity, Fig. 3b) quickly reintroduced nutrients into the euphotic zone and sustained high proportions of large diatoms (Fig. 4b and Online Resource 4b: data on $12 \mathrm{Feb}$ ).

In contrast to $\mathrm{S} 2$, the $\mathrm{B} 2$ period in S1 was largely dominated by Cryptophyceae (Fig. 4), which were found to be associated with high temperature and light availability (Figs. 5, 9). Temperature and light have previously been reported as the most likely factors promoting Cryptophyceae in the WAP (Kopczynska 1992), and Buma et al. (1993) reported maximum division rates of Antarctic cryptophytes at $1{ }^{\circ} \mathrm{C}$ and $50 \mu \mathrm{mol}$ quanta $\mathrm{m}^{-2} \mathrm{~s}^{-1}$, similar to B2 in $\mathrm{S} 1$ of this study. Mendes et al. (2017) also described strong positive correlations between cryptophytes and temperature in WAP waters. Although some studies linked reduced salinity with cryptophytes (Buma et al. 1992; Moline et al. 1997, 2004; Mendes et al. 2013), our study displays only a weak association with salinity (Figs. 5, 9). It may be that previous associations of cryptophytes with salinity were largely driven by collinearity between salinity and temperature. Alternatively, differences in species-specific responses to environmental variables could also be responsible for the variances observed (Henley et al. 2019).

Phaeocystis (Phyto III) was one of the most abundant FCM groups consistently present during both seasons (Fig. 6c). Phyto III dynamics were largely associated with light availability (PAR and $Z_{\mathrm{eu}} / 15 \mathrm{~m}$ ) and salinity, factors also important for Prymnesiophyceae (Figs. 5, 9), with the highest abundances occurring during a period of relatively low salinity (B2 in S2; Figs. 6c, 3b). Phaeocystis antarctica has been reported to tolerate low salinity better than high salinity (Bates and Cota 1986; Van Leeuwe et al. 2014) and display decreased photosynthetic activity in response to higher salinity and lower temperatures (Kennedy et al. 2012). Additionally, P. antarctica appears to have efficient photosystem and photo-damage repair mechanisms, enabling it to grow at higher PAR and in well-mixed waters (Kropuenske et al. 2009; Alderkamp et al. 2012). Finally, $P$. antarctica growth rate has been reported to increase with the temperature (Schoemann et al. 2005; Rose et al. 2009; Lee et al. 2016), supporting our finding that Phyto III is also associated with the increasing temperature.

Towards the end of the productive season (B3 period), a large and prolonged bloom of nano-sized diatoms (Phyto VI and IX; Fig. 6f, i) was observed in S1 but not present in S2. Phyto VI correlated with relatively high temperature, PAR and phosphate (sustained by deeper mixing; Figs. 2d, 5, and 9). As Phyto VI peaked in abundance, PAR declined, light became potentially limiting, and the shallowed MLD resulted in a rapid decrease in phosphate. Subsequently, Phyto IX bloomed under conditions of reduced phosphate (however sustained by regular mixing) and low light availability $\left(<3 \mu\right.$ mol quanta $\left.\mathrm{m}^{-2} \mathrm{~s}^{-1}\right)$. Blooms of Phyto IX only occurred when biomass accumulation reduced light to potentially limiting levels. Conversely, higher light conditions in S2 may have reduced Phyto IXs competitive advantage under low light and restricted bloom development when PAR and $Z_{\text {eu }} / 15 \mathrm{~m}$ were higher (Fig. 2c, d). Specifically during B3 in S2, low temperature may have restricted the accumulation of Phyto VI (Suzuki and Takahashi 1995; Montagnes and Franklin 2001) and consequently the relatively reduced light attenuation (lack of community shading) would have prevented Phyto IX to bloom and increase Chl-a concentrations further.

\section{Losses}

The environmental variables were unable to explain all of the variabilities in phytoplankton abundance and community composition in Ryder Bay. The remaining variation is likely an indication for the importance of loss factors in structuring phytoplankton communities (Yang et al. 2016; Mojica et al. 2016). Biomass accumulation is after all the net result of production (regulated by physical and chemical variables) and loss rates such as grazing and viral lysis. The decline in phytoplankton biomass in S2 mid-February (end of B2) and the reduced $\mathrm{Chl}-\mathrm{a}$ concentrations during B3 (compared to S1) may have been, at least partly, due to relatively high grazing pressure. Meso-zooplankton numbers peaked just before the start of the B3 period in S2, whereas numbers were declining at the same time in S1 (Online Resource 11). For both seasons, the period with enhanced zooplankton standing stock coincided with a distinct rise in ammonium concentrations. Although the temporal dynamics of ammonium seems related to mixing events, similar to the other macronutrients (Online Resource 3), micro- and meso-zooplankton are known to excrete ammonium (Goeyens 1991; Brussaard et al. 1996; Atkinson and Whitehouse 2000).

The B2 period in S1 was cryptophytes-dominated with relatively low abundances of diatoms. Krill have been shown to selectively graze diatoms, rather than cryptophytes or prymnesiophytes, even when diatoms were rare (Verity and Smayda 1989; Head and Harris 1994; Haberman et al. 2003). Furthermore, Kopczynska (1992) showed that in WAP coastal waters, low biomass areas dominated by flagellates also host dense krill swarms. This suggests that water column stability and zooplankton grazing act together to regulate phytoplankton community structure by reducing the biomass of diatoms and may suppress the development of a phytoplankton bloom. Besides grazing, viral lysis may contribute to the selective removal of phytoplankton (Brussaard 2004), influencing both species and strain diversity. 
Furthermore, high temperatures during B2 of S1 may have promoted phytoplankton losses due to viral lysis, related to a shorter virus latent period and increased burst size (Maat et al. 2017; Piedade et al. 2018).

\section{Combining methods}

The combined approach of using FCM (abundances), CHEMTAX (taxonomic composition) and size structure provides a more detailed understanding of the structure and composition of natural phytoplankton communities. Together with multivariate statistics, these methods increased the size spectrum of the study community and enabled the differentiation and comparison of individual size classes and chemotaxonomy within different bloom periods, as well as identifying physicochemical associations. This enabled predictions regarding the taxonomy of various phytoplankton groups identified by FCM (e.g. prymnesiophyte Phyto III) and allowed for a better discrimination within an individual taxonomic group (i.e. diatom populations Phyto $\mathrm{V}-\mathrm{X}$ ). Diatoms dominated the biomass generally throughout both seasons and in all size classes, however, Chl-a-based CCAs could not assign strong drivers to this group. It can be expected that each size class (and each population within that size class) is driven by different environmental variables, preventing the assignment of reliable associations to this diverse taxonomic group. This oversimplification was avoided by defining populations via FCM which provided the greater resolution needed to understand the relationship between populations and environmental factors.

\section{Conclusions}

The current study provides a high-resolution temporal description of phytoplankton, particularly the pico- and nano-size fractions, and the physical and chemical characteristics over two distinct productive seasons. Multivariate analysis revealed that ice type was the most influential differential factor on phytoplankton community composition during spring and early summer, whereas temperature, light, phosphate and salinity played a more influential role during late summer and autumn. Ice type rather than ice cover structured the pre-bloom phytoplankton community as well as the size class of the summer phytoplankton bloom. Maximum biomass accumulation was regulated by light and nutrient (mainly phosphate) availabilities which in turn were regulated by wind-driven mixing events. Prolonged salinity-driven stratification combined with moderate mixing and seawater temperature $>0{ }^{\circ} \mathrm{C}$ (supplying $\mathrm{DFe}$ from ice melt) coincided with the development of a large ( $>20 \mu \mathrm{m}$ ) diatom-dominated phytoplankton community. Flagellates were associated with late summer conditions of high temperature (Cryptophyceae), low salinity and high light availability (Prymnesiophyceae) and would likely be more dominant under a warmer future climate with earlier and prolonged stratification (Falkowski and Oliver 2007). In a future 'warmer' autumn, which follows on from a 'warmer' summer, we would expect to see an increased frequency of large and prolonged nano-sized diatom blooms as observed during B3 in S1. To improve the variance explained by Chla-based CCAs, we recommend performing frequent $\mathrm{Chl}-\mathrm{a}$ fractionations. One caveat is that multiple FCM groups can fall into the same Chl-a size fraction, and if driven by different factors, this would lead to confounding results. FCM, however, provides fundamental information (for the $\leq 20 \mu \mathrm{m}$ size fraction) on the abundances of the various populations while enhancing the ability to differentiate important physicochemical correlations with phytoplankton community structure and thus provides a vital tool for studying phytoplankton dynamics. The addition of large cell flow cytometry and high through-put sequencing of sorted phytoplankton populations (Eiler et al. 2013; Johnson and Martiny 2015; Massana et al. 2015; Visco et al. 2015), would enhance analysis of the phytoplankton community.

Acknowledgements We wish to thank the British Antarctic Survey for their logistical support and cooperation during the field campaign. This work was part of the ANTPHIRCO project (grant 866.10.102 awarded to C.P.D.B.) which was supported by the Earth and Life Sciences Foundation (ALW), with financial aid from the Netherlands Organisation for Scientific Research (NWO). Furthermore, we wish to thank Zoi Farenzena and Dorien Verheyen for their help and support during the field campaign as well as Swier Oosterhuis and Anna Noordeloos for their technical support at the Royal Netherlands Institute for Sea Research (NIOZ).

\section{Compliance with ethical standards}

Conflict of interest The authors declare that they have no conflict of interest.

Open Access This article is distributed under the terms of the Creative Commons Attribution 4.0 International License (http://creativeco mmons.org/licenses/by/4.0/), which permits unrestricted use, distribution, and reproduction in any medium, provided you give appropriate credit to the original author(s) and the source, provide a link to the Creative Commons license, and indicate if changes were made.

\section{References}

Agirbas E, Feyzioglu AM, Kopuz U, Llewellyn CA (2015) Phytoplankton community composition in the south-eastern Black Sea determined with pigments measured by HPLC-CHEMTAX analyses and microscopy cell counts. J Mar Biol Assoc UK 95:35-52. https://doi.org/10.1017/S0025315414001040

Agustí S, Duarte CM (2013) Phytoplankton lysis predicts dissolved organic carbon release in marine plankton communities. 
Biogeosciences 10:1259-1264. https://doi.org/10.5194/ bg-10-1259-2013

Alderkamp AC, Mills MM, van Dijken GL et al (2012) Iron from melting glaciers fuels phytoplankton blooms in the Amundsen Sea (Southern Ocean): Phytoplankton characteristics and productivity. Deep Res Part II 71-76:32-48. https://doi.org/10.1016/j. dsr2.2012.03.005

Álvarez E, Nogueira E, López-Urrutia Á (2017) In vivo single-cell fluorescence and size scaling of phytoplankton chlorophyll content. Appl Environ Microbiol 83:1-16. https://doi.org/10.1128/ aem.03317-16

Arrigo KR (2003) Physical control of chlorophyll $a$, POC, and TPN distributions in the pack ice of the Ross Sea, Antarctica. J Geophys Res 108:3316. https://doi.org/10.1029/2001JC001138

Atkinson A, Whitehouse MJ (2000) Ammonium excretion by Antarctic krill Euphausia superba at South Georgia. Limnol Oceanogr 45:1012. https://doi.org/10.4319/lo.2000.45.4.1012

Atkinson A, Siegel V, Pakhomov EA, Rothery P (2004) Long-term decline in krill stock and increase in salps within the Southern Ocean. Nature 432:100-103. https://doi.org/10.1038/nature0295 0.1

Bates SS, Cota GF (1986) Fluorescence induction and photosynthetic response of Arctic ice algae to sample treatment and salinity. J Phycol 22:421-429

Beardall J, Stojkovic S (2006) Microalgae under global environmental change: implications for growth and productivity, populations and trophic flow. ScienceAsia 32(s1):001. https://doi. org/10.2306/scienceasia1513-1874.2006.32(s1).001

Bown J, Laan P, Ossebaar S et al (2017) Bioactive trace metal time series during Austral summer in Ryder Bay, Western Antarctic Peninsula. Deep Sea Res Part II 139:103-119. https://doi. org/10.1016/j.dsr2.2016.07.004

Boyce DG, Lewis MR, Worm B (2010) Global phytoplankton decline over the past century. Nature 466:591-596. https://doi. org/10.1038/nature09268

Brussaard CPD (2004) Viral control of phytoplankton populationsa review. J Eukaryot Microbiol 51:125-138. https://doi. org/10.1111/j.1550-7408.2006.volcontents_1.x

Brussaard CPD, Gast GJ, Van Duyl FC, Riegman R (1996) Impact of phytoplankton bloom magnitude on a pelagic microbial food web. Mar Ecol Prog Ser 144:211-221. https://doi.org/10.3354/ meps144211

Brussaard CPD, Peperzak L, Beggah S et al (2016) Immediate ecotoxicological effects of short-lived oil spills on marine biota. Nat Commun 7:1-11. https://doi.org/10.1038/ncomms11206

Buma AGJ, Gieskes WWC, Thomsen HA (1992) Abundance of cryptophyceae and chlorophyll b-containing organisms in the Weddell-Scotia Confluence area in the spring of 1988. Polar Biol 12:43-52. https://doi.org/10.1007/BF00239964

Buma AGJ, Noordeloos AAM, Larsen J (1993) Strategies and kinetics of photoacclimation in three Antarctic nanophytoflagellates. J Phycol. https://doi.org/10.1111/j.1529-8817.1993.tb00141.x

Christaki U, Obernosterer I, Van Wambeke F et al (2008) Microbial food web structure in a naturally iron-fertilized area in the Southern Ocean (Kerguelen Plateau). Deep Res Part II 55:706-719. https://doi.org/10.1016/j.dsr2.2007.12.009

Clarke A, Meredith MP, Wallace MI et al (2008) Seasonal and interannual variability in temperature, chlorophyll and macronutrients in northern Marguerite Bay, Antarctica. Deep Res Part II 55:19882006. https://doi.org/10.1016/j.dsr2.2008.04.035

Conan P, Søndergaard M, Kragh T et al (2007) Partitioning of organic production in marine plankton communities: the effects of inorganic nutrient ratios and community composition on new dissolved organic matter. Limnol Oceanogr 52:753-765. https://doi. org/10.4319/lo.2007.52.2.0753
Deppeler SL, Davidson AT (2017) Southern Ocean phytoplankton in a changing climate. Front Mar Sci. https://doi.org/10.3389/fmars .2017.00040

Eiler A, Drakare S, Bertilsson S et al (2013) Unveiling distribution patterns of freshwater phytoplankton by a next generation sequencing based approach. PLoS ONE 8:1-10. https://doi.org/10.1371/ journal.pone. 0053516

Evans C, Brandsma J, Pond DW et al (2017) Drivers of interannual variability in virioplankton abundance at the coastal western Antarctic peninsula and the potential effects of climate change. Environ Microbiol 19:740-755. https://doi.org/10.1111/1462-2920.13627

Eveleth R, Cassar N, Sherrell RM et al (2017) Ice melt influence on summertime net community production along the Western Antarctic Peninsula. Deep Res Part II 139:89-102. https://doi. org/10.1016/j.dsr2.2016.07.016

Falkowski PG, Oliver MJ (2007) Mix and match: how climate selects phytoplankton. Nat Rev Microbiol 5:966. https://doi.org/10.1038/ nrmicro1792

Finkel ZV, Beardall J, Flynn KJ et al (2010) Phytoplankton in a changing world: cell size and elemental stoichiometry. J Plankton Res 32:119-137. https://doi.org/10.1093/plankt/fbp098

Froneman PW, Perissinotto R (1996) Microzooplankton grazing and protozooplankton community structure in the South Atlantic and in the Atlantic sector of the Southern Ocean. Deep Sea Res Part I 43:703-721. https://doi.org/10.1016/0967-0637(96)00010-6

Garibotti IA, Vernet M, Kozlowski WA, Ferrario ME (2003) Composition and biomass of phytoplankton assemblages in coastal Antarctic waters: a comparison of chemotaxonomic and microscopic analyses. Mar Ecol Prog Ser 247:27-42. https://doi.org/10.3354/ meps 247027

Garibotti IA, Vernet M, Smith RC, Ferrario ME (2005) Interannual variability in the distribution of the phytoplankton standing stock across the seasonal sea-ice zone west of the Antarctic Peninsula. J Plankton Res 27:825-843. https://doi.org/10.1093/plankt/fbi05 6

Garrison DL, Buck KR, Fryxell GA (1987) Algal assemblages in Antarctic pack ice and in ice-edge plankton. J Phycol 23:564-572. https://doi.org/10.1111/j.1529-8817.1987.tb04206.x

Garrison D, Gowing M, Hughes M et al (2000) Microbial food web structure in the Arabian Sea: a US JGOFS study. Deep Sea Res Part II 47:1387-1422. https://doi.org/10.1016/S0967 -0645(99)00148-4

Geider RJ (1987) Light and temperature dependence of the carbon to chlorophyll a ratio in microalgae and cyanobacteria: implications for physiology and growth of phytoplankton. New Phytol 106:1-34. https://doi.org/10.1111/j.1469-8137.1987.tb04788.x

Goeyens L (1991) Ammonium regeneration in the Scotia-Weddell Confluence area during spring 1988. Mar Ecol Prog Ser 78:241-252. https://doi.org/10.3354/meps078241

Gonçalves-Araujo R, de Souza MS, Tavano VM, Garcia CAE (2015) Influence of oceanographic features on spatial and interannual variability of phytoplankton in the Bransfield Strait, Antarctica. J Mar Syst 142:1-15. https://doi.org/10.1016/j.jmars ys.2014.09.007

Graníi E, Granéli W, Rabbani MM et al (1993) The influence of copepod and krill grazing on the species composition of phytoplankton communities from the Scotia Weddell sea. Polar Biol 13:201-213. https://doi.org/10.1007/BF00238930

Haberman KL, Quetin LB, Ross RM (2003) Diet of the Antarctic krill (Euphausia superba Dana). J Exp Mar Biol Ecol 283:79-95. https://doi.org/10.1016/S0022-0981(02)00466-5

Hallegraeff GM (2010) Ocean climate change, phytoplankton community responses, and harmful algal blooms: a formidable predictive challenge. J Phycol 46:220-235. https://doi.org/10.111 $1 / \mathrm{j} .1529-8817.2010 .00815 . \mathrm{x}$ 
Harbison GR, McAlister VL, Gilmer RW (1986) The response of the salp, Pegea confoederata, to high levels of particulate material: starvation in the midst of plenty1. Limnol Oceanogr 31:371-382. https://doi.org/10.4319/lo.1986.31.2.0371

Hashihama F, Hirawake T, Kudoh S et al (2008) Size fraction and class composition of phytoplankton in the Antarctic marginal ice zone along the $140^{\circ} \mathrm{E}$ meridian during February-March 2003. Polar Sci 2:109-120. https://doi.org/10.1016/j.polar.2008.05.001

Head EJH, Harris LR (1994) Feeding selectivity by copepods grazing on natural mixtures of phytoplankton determined by HPLC analysis of pigments. Mar Ecol Prog Ser 110:75-84. https://doi. org/10.3354/meps110075

Henley SF, Schofield OM, Hendry KR et al (2019) Variability and change in the west Antarctic Peninsula marine system: research priorities and opportunities. Prog Oceanogr 173:208-237. https ://doi.org/10.1016/j.pocean.2019.03.003

Jacques G, Panouse M (1991) Biomass and composition of size fractionated phytoplankton in the Weddell-Scotia confluence area. Polar Biol 11:315-328. https://doi.org/10.1007/BF00239024

Jin M, Deal C, Wang J et al (2007) Ice-associated phytoplankton blooms in the southeastern Bering Sea. Geophys Res Lett 34:1-6. https://doi.org/10.1029/2006GL028849

Johnson ZI, Martiny AC (2015) Techniques for quantifying phytoplankton biodiversity. Ann Rev Mar Sci 7:299-324. https://doi. org/10.1146/annurev-marine-010814-015902

Kennedy F, McMinn A, Martin A (2012) Effect of temperature on the photosynthetic efficiency and morphotype of Phaeocystis antarctica. J Exp Mar Bio Ecol 429:7-14. https://doi.org/10.1016/j. jembe.2012.06.016

Kim H, Ducklow HW, Abele D et al (2018) Correction to 'Inter-decadal variability of phytoplankton biomass along the coastal West Antarctic Peninsula'. Philos Trans R Soc A 376:20180170. https ://doi.org/10.1098/rsta.2018.0170

Kopczynska EE (1992) Dominance of microflagellates over diatoms in the Antarctic areas of deep vertical mixing and krill concentrations. J Plankton Res 14:1031-1054. https://doi.org/10.1093/ plankt/14.8.1031

Kozlowski WA, Deutschman D, Garibotti I et al (2011) An evaluation of the application of CHEMTAX to Antarctic coastal pigment data. Deep Res Part I 58:350-364. https://doi.org/10.1016/j. dsr.2011.01.008

Kropuenske LR, Mills MM, van Dijken GL et al (2009) Photophysiology in two major Southern Ocean phytoplankton taxa: photoprotection in Phaeocystis antarctica and Fragilariopsis cylindrus. Limnol Oceanogr 54:1176-1196. https://doi.org/10.4319/ lo.2009.54.4.1176

Lee Y, Yang EJ, Park J et al (2016) Physical-biological coupling in the Amundsen Sea, Antarctica: influence of physical factors on phytoplankton community structure and biomass. Deep Sea Res Part I 117:51-60. https://doi.org/10.1016/j.dsr.2016.10.001

Li WKW, Dickie PM (2001) Monitoring phytoplankton, bacterioplankton, and virioplankton in a coastal inlet (Bedford Basin) by flow cytometry. Cytometry 44:236-246. https://doi.org/10.1002/10970320(20010701)44:3\%3c236:AID-CYTO1116\%3e3.0.CO;2-5

Llewellyn CA, Fishwick JR, Blackford JC (2005) Phytoplankton community assemblage in the English Channel: a comparison using chlorophyll a derived from HPLC-CHEMTAX and carbon derived from microscopy cell counts. J Plankton Res 27:103119. https://doi.org/10.1093/plankt/fbh158

Loeb VJ, Siegel V, Holm-Hansen O et al (1997) Effects of sea-ice extent and krill or salp dominance on the Antarctic food web. Nature 387:879-900. https://doi.org/10.1038/43174

Maat DS, Biggs T, Evans C et al (2017) Characterization and temperature dependence of arctic Micromonas polaris viruses. Viruses 9:6-9. https://doi.org/10.3390/v9060134
Mackey MD, Mackey DJ, Higgins HW, Wright SW (1996) CHEMTAX - a program for estimating class abundances from chemical markers: application to HPLC measurements of phytoplankton. Mar Ecol Prog Ser 144:265-283. https://doi. org/10.3354/meps 144265

Marañón E (2015) Cell size as a key determinant of phytoplankton metabolism and community structure. Ann Rev Mar Sci 7:241264. https://doi.org/10.1146/annurev-marine-010814-015955

Marie D, Partensky F, Vaulot D, Brussaard C (1999) Enumeration of phytoplankton, bacteria, and viruses in marine samples. Curr Protoc Cytom 10:11-11. https://doi.org/10.1002/0471142956 .cy1111s10

Massana R, Gobet A, Audic S et al (2015) Marine protist diversity in European coastal waters and sediments as revealed by highthroughput sequencing. Environ Microbiol 17:4035-4049. https ://doi.org/10.1111/1462-2920.12955

Mendes CRB, Tavano VM, Leal MC et al (2013) Shifts in the dominance between diatoms and cryptophytes during three late summers in the Bransfield Strait (Antarctic Peninsula). Polar Biol 36:537-547. https://doi.org/10.1007/s00300-012-1282-4

Mendes CRB, Tavano VM, Dotto TS et al (2017) New insights on the dominance of cryptophytes in Antarctic coastal waters: a case study in Gerlache Strait. Deep Res Part II. https://doi. org/10.1016/j.dsr2.2017.02.010

Mojica KDA, Huisman J, Wilhelm SW, Brussaard CPD (2016) Latitudinal variation in virus-induced mortality of phytoplankton across the North Atlantic Ocean. ISME J 10:500-513. https:// doi.org/10.1038/ismej.2015.130

Moline MA, Prezelin BB (1996) Long-term monitoring and analyses of physical factors regulating variability in coastal Antarctic phytoplankton composition over seasonal and interannual timescales. Mar Ecol Prog Ser 145:143-160. https://doi.org/10.3354/Meps1 45143

Moline MA, Prezelin BB, Schofield OM, Smith RC (1997) Temporal dynamics of coastal Antarctic phytoplankton: Environmental driving forces and impact of a 1991/92 summer diatom bloom on the nutrient regimes. In: Battaglia B, Valencia $\mathrm{H}$, Walton DWH (eds) Antarctic communities: Species, structure and survival. Cambridge University Press, pp 67-72

Moline MA, Claustre H, Frazer TK et al (2004) Alteration of the food web along the Antarctic Peninsula in response to a regional warming trend. Glob Chang Biol 10:1973-1980. https://doi.org /10.1111/j.1365-2486.2004.00825.x

Montagnes DJS, Franklin M (2001) Effect of temperature on diatom volume, growth rate, and carbon and nitrogen content: reconsidering some paradigms. Limnol Oceanogr 46:2008-2018. https ://doi.org/10.4319/lo.2001.46.8.2008

Montagnes DJS, Berges JA, Harrison PJ, Taylor FJR (1994) Estimating carbon, nitrogen, protein, and chlorophyll a from volume in marine phytoplankton. Limnol Oceanogr 39:1044-1060. https:// doi.org/10.4319/lo.1994.39.5.1044

Montes-Hugo M, Doney SC, Ducklow HW et al (2009) Recent changes in phytoplankton communities associated with rapid regional climate change along the Western Antarctic Peninsula. Science 323(5920):1470-1473. https://doi.org/10.1126/science.1164533

Moreau S, Mostajir B, Bélanger S et al (2015) Climate change enhances primary production in the western Antarctic Peninsula. Glob Chang Biol 21:2191-2205. https://doi.org/10.1111/gcb.12878

Obernosterer I, Christaki U, Lefèvre D et al (2008) Rapid bacterial mineralization of organic carbon produced during a phytoplankton bloom induced by natural iron fertilization in the Southern Ocean. Deep Res Part II 55:777-789. https://doi.org/10.1016/j. dsr2.2007.12.005 
Oksanen J, Blanchet FG, Friendly M, et al (2013) Vegan: Community ecology package. R Packag version 23-2 https://CRAN.R-proje ct.org/package $=$ vegan

Perissinotto RA, Pakhomov E (1998) The trophic role of the tunicate Salpa thompsoni in the Antarctic marine ecosystem. J Mar Syst 17:361-374. https://doi.org/10.1016/S0924-7963(98)00049-9

Petrou K, Hill R, Doblin MA et al (2011) Photoprotection of sea-ice microalgal communities from the east antarctic pack ice. J Phycol 47:77-86. https://doi.org/10.1111/j.1529-8817.2010.00944.x

Piedade GJ, Wesdorp EM, Borbolla EM, Maat DS (2018) Influence of irradiance and temperature on the virus MpoV-45T infecting the Arctic picophytoplankter Micromonas polaris. Viruses 10(12):1-17

Pinhassi J, Sala MM, Havskum H et al (2004) Changes in bacterioplankton composition under different phytoplankton regimens. Appl Environ Microbiol 70:6753-6766. https://doi.org/10.1128/ AEM.70.11.6753-6766.2004

Quetin LB, Ross RM (1985) Feeding by Antarctic krill, Euphausia superba: does size matter? In: Siegfried WR, Condy PR, Laws RM (eds) Antarctic nutrient cycles and food webs. Springer, Berlin, pp 372-377

R Development Core Team (2012) R: A language and environment for statistical computing, Vienna, Austria: R foundation for statistical computing. Retrieved from http://www.R-project.org

Riegman R, Kuipers BR, Noordeloos AAM, Witte HJ (1993) Sizedifferential control of phytoplankton and the structure of plankton communities. Neth J Sea Res 31:255-265. https://doi. org/10.1016/0077-7579(93)90026-O

Robinson DH, Arrigo KR, Iturriaga R, Sullivan CW (1995) Microalgal light-harvesting in extreme low-light environments in McMurdo Sound, Antarctica. J Phycol 31:508-520. https://doi. org/10.1111/j.1529-8817.1995.tb02544.x

Robinson DH, Kolber Z, Sullivan CW (1997) Photophysiology and photoacclimation in surface sea ice algae from McMurdo Sound, Antarctica. Mar Ecol Prog Ser 147:243-256. https://doi. org/10.3354/meps147243

Rodriguez F, Varela M, Zapata M (2002) Phytoplankton assemblages in the Gerlache and Bransfield Straits (Antarctic Peninsula) determined by light microscopy and CHEMTAX analysis of HPLC pigment data. Deep Sea Res Part II 49:723-747. https://doi. org/10.1016/S0967-0645(01)00121-7

Rose JM, Feng Y, DiTullio GR et al (2009) Synergistic effects of iron and temperature on Antarctic phytoplankton and microzooplankton assemblages. Biogeosciences 6:3131-3147. https:// doi.org/10.5194/bg-6-3131-2009

Rozema PD, Biggs T, Sprong PAA et al (2017a) Summer microbial community composition governed by upper-ocean stratification and nutrient availability in northern Marguerite Bay, Antarctica. Deep Res Part II 139:151-166. https://doi.org/10.1016/j. dsr2.2016.11.016

Rozema PD, Kulk G, Veldhuis MP et al (2017b) Assessing drivers of coastal primary production in northern Marguerite Bay, Antarctica. Front Mar Sci 4:1-20. https://doi.org/10.3389/fmars.2017.00184

Rozema PD, Venables HJ, van de Poll WH et al (2017c) Interannual variability in phytoplankton biomass and species composition in northern Marguerite Bay (West Antarctic Peninsula) is governed by both winter sea ice cover and summer stratification. Limnol Oceanogr 62:235-252. https://doi.org/10.1002/lno.10391

Saba GK, Fraser WR, Saba VS et al (2014) Winter and spring controls on the summer food web of the coastal West Antarctic Peninsula. Nat Commun 5:4318. https://doi.org/10.1038/ncomms5318

Schoemann V, Becquevort S, Stefels J et al (2005) Phaeocystis blooms in the global ocean and their controlling mechanisms: a review. J Sea Res 53:43-66. https://doi.org/10.1016/j.seares.2004.01.008

Schofield O, Ducklow HW, Martinson DG et al (2010) How do polar marine ecosystems respond to rapid climate change? Science 328:1520-1523. https://doi.org/10.1126/science.1185779
Schofield O, Brown M, Kohut J et al (2018) Changing upper ocean mixed layer depth and phytoplankton productivity along the West Antarctic Peninsula. Philos Trans R Soc A 376(2122):20170174. https://doi.org/10.1098/rsta.2017.0173

Smetacek V, Nicol S (2005) Polar ocean ecosystems in a changing world. Nature 437:362-368. https://doi.org/10.1038/nature04161

Steinberg DK, Ruck KE, Gleiber MR et al (2015) Long-term (19932013) changes in macrozooplankton off the western antarctic peninsula. Deep Res Part I 101:54-70. https://doi.org/10.1016/j. dsr.2015.02.009

Suzuki Y, Takahashi M (1995) Growth responses of several diatom species isolated from various environments to temperature. J Phycol 31:880-888. https://doi.org/10.1111/j.0022-3646.1995.00880.x

Timmermans KR, Davey MS, Van der Wagt B et al (2001) Co-limitation by iron and light of Chaetoceros brevis, $C$. dichaeta and $C$. calcitrans (Bacillariophyceae). Mar Ecol Prog Ser 217:287-297. https://doi.org/10.3354/meps217287

Van De Poll WH, Lagunas M, De Vries T et al (2011) Non-photochemical quenching of chlorophyll fluorescence and xanthophyll cycle responses after excess PAR and UVR in Chaetoceros brevis, Phaeocystis antarctica and coastal Antarctic phytoplankton. Mar Ecol Prog Ser 426:119-131. https://doi.org/10.3354/meps09000

Van Leeuwe MA, Visser RJW, Stefels J (2014) The pigment composition of Phaeocystis antarctica (Haptophyceae) under various conditions of light, temperature, salinity, and iron. J Phycol 50:1070-1080. https://doi.org/10.1111/jpy.12238

Vaulot D (1989) CYTOPC: processing software for flow cytometric data. Signal Noise 2:8

Veldhuis MJW, Kraay GW (2004) Phytoplankton in the subtropical Atlantic Ocean: towards a better assessment of biomass and composition. Deep Res Part I 51:507-530. https://doi.org/10.1016/j. dsr.2003.12.002

Venables HJ, Clarke A, Meredith MP (2013) Wintertime controls on summer stratification and productivity at the western Antarctic Peninsula. Limnol Oceanogr 58:1035-1047. https://doi. org/10.4319/lo.2013.58.3.1035

Verity PG, Smayda TJ (1989) Nutritional value of Phaeocystis pouchetii (Prymnesiophyceae) and other phytoplankton for Acartia spp. (Copepoda): ingestion, egg production, and growth of nauplii. Mar Biol 100:161-171. https://doi.org/10.1007/BF00391955

Visco JA, Apothéloz-Perret-Gentil L, Cordonier A et al (2015) Environmental monitoring: inferring the diatom index from nextgeneration sequencing data. Environ Sci Technol 49:7597-7605. https://doi.org/10.1021/es506158m

Worden AZ, Nolan JK, Palenik B (2004) Assessing the dynamics and ecology of marine picophytoplankton: the importance of the eukaryotic component. Limnol Oceanogr 49:168-179. https:// doi.org/10.4319/lo.2004.49.1.0168

Wulff A, Wängberg S- $\AA$ (2004) Spatial and vertical distribution of phytoplankton pigments in the eastern Atlantic sector of the Southern Ocean. Deep Sea Res Part II 51:2701-2713. https:// doi.org/10.1016/j.dsr2.2001.01.002

Yang EJ, Jiang Y, Lee SH (2016) Microzooplankton herbivory and community structure in the Amundsen Sea, Antarctica. Deep Res Part II 123:58-68. https://doi.org/10.1016/j.dsr2.2015.06.001

Zuur AF, Ieno EN, Walker N et al (2009) Mixed effects models and extensions in ecology with R. Springer, New York. https://doi. org/10.1007/978-0-387-87458-6

Zuur AF, Ieno EN, Elphick CS (2010) A protocol for data exploration to avoid common statistical problems. Methods Ecol Evol 1:3-14. https://doi.org/10.1111/j.2041-210X.2009.00001.x

Publisher's Note Springer Nature remains neutral with regard to jurisdictional claims in published maps and institutional affiliations. 